\title{
Zespoły komórek płciowych w gametogenezie zwierząt - geneza, organizacja i funkcjonowanie
}

\section{STRESZCZENIE}

W trakcie wczesnej gametogenezy zwierząt pojawiają się nietypowe podziały mitotyczne komórek płciowych, które nie kończą się pełną cytokinezą. W konsekwencji potomne komórki nie są kompletnie rozdzielone ale pozostają przez pewien czas połączone zmodyfikowanymi pierścieniami zaciskowymi zwanymi stabilnymi mostkami międzykomórkowymi. Mostki te to na tyle szerokie pasma cytoplazmy (od $0,2 \mu \mathrm{m}$ do $20 \mu \mathrm{m}$ ), że możliwa jest wymiana zarówno produktów genowych jak i organelli pomiędzy połączonymi komórkami. Takie syncytialne twory nazywamy zespołami (cystami) komórek płciowych. Zespoły występują powszechnie $\mathrm{w}$ trakcie spermatogenezy zwierząt łącząc $\mathrm{z}$ sobą męskie komórki płciowe aż do ich przekształcenia w plemniki. W linii żeńskiej (oogeneza) zespoły mogą się w ogóle nie formować, powstają na bardzo krótki czas (do początku mejozy) lub na dłużej (do zaawansowanej oogenezy). Pomimo uniwersalnego mechanizmu powstawania zespolów (niepełna cytokineza) obserwujemy dużą różnorodność w ich organizacji przestrzennej i funkcjonowaniu. Niniejszy artykuł przedstawia podstawowe fakty związane z powstawaniem i funkcjonowaniem zespołów komórek płciowych w linii męskiej i żeńskiej.

\section{WSTĘP CZYLI CO TO SĄ ZESPOŁY KOMÓREK PŁCIOWYCH}

W czasie gametogenezy komórki linii płciowej wpierw przechodzą liczne podziały mitotyczne, później podziały mejotyczne i znacząco zmieniają swoją morfologię i właściwości cytochemiczne by finalnie stać się bardzo wyspecjalizowanymi komórkami rozrodczymi (gametami) [1]. W świecie zwierząt wielokomórkowych proces formowania się gamet (gametogeneza) zachodzi zazwyczaj w wyspecjalizowanych narządach czyli gonadach, rzadko, np. u gąbek, pewnych parzydełkowców, wirków bezjelitowych, niektórych wieloszczetów mamy do czynienia z tzw. gametogenezą rozproszoną - dyfuzyjną, gdzie nie formują się gonady [1,2]. Intrygującym jest fakt, iż w większości przypadków komórki płciowe przechodzące proces formowania nie funkcjonują jako indywidualne komórki, ale jako zespoły komórek połączonych bezpośrednio z sobą szerokimi kanałami cytoplazmatycznymi (Ryc. 1, 2, 3) [3-11]. Przeczy to naszym szkolnym, schematycznym wyobrażeniom o procesach spermatogenezy i oogenezy, gdzie każda komórka płciowa przedstawiana jest jako struktura funkcjonująca indywidualnie a fakt ich połączenia $\mathrm{w}$ zespoły jest zazwyczaj pomijany. Czym są zespoły komórek płciowych (ZKP)? Jaka jest ich rola? Jak powstają, jak wyglądają i funkcjonują? Oto główne pytania na które Czytelnik znajdzie w niniejszym opracowaniu odpowiedzi. Ze względu na ograniczoną objętość pracy nie będą to jednak odpowiedzi w pełni wyczerpujące a zainteresowanego Czytelnika odsyłamy do opracowań bardziej szczegółowych [3-12].

Czym są ZKP (zwane także cystami, gronami, grupami izogenicznymi czy gniazdami)? Są to komórki linii płciowej, które przechodzą proces gametogenezy (lub przynajmniej część tego procesu) jako komórki połączone wyspecjalizowanymi połączeniami międzykomórkowymi (Ryc. 1, 2, 3). Połączenia te nazywamy stabilnymi mostkami międzykomórkowymi (SMM) i mają one postać relatywnie szerokich (o średnicy od 0,2 $\mu \mathrm{m}$ do nawet $20 \mu \mathrm{m}$ ) kanałów cytoplazmatycznych przez które może zachodzić wymiana cytoplazmy wraz z jej zawartością, czyli np. wymiana makrocząsteczek i organelli [3,4,13,5-12]. SMM nie są trwałe i ulegają zamknięciu bądź to wraz z końcem gametogenezy bądź znacząco wcześniej (np. wraz z wejściem komórek płciowych w proces mejozy). Dzięki istnieniu takich szerokich kanałów komunikacyjnych i wymianie zawartości cytoplazmy można uznać, że połączone z sobą komórki tworzą funkcjonalne syncytium (Ryc. 1). Tak więc warunkiem koniecznym by powstały ZKP jest istnienie między nimi szerokich kanałów cytoplazmatycznych w formie SMM. Stabilne mostki międzykomórkowe to niezamknięte przez pewien czas pierścienie zaciskowe, czyli struktury odpowiadające za rozdzielenie się komórek (cytokinezę) w końcowej fazie podziału komórkowego [3-5,14]. Jeśli pod koniec cytokinezy pierścień zaciskowy nie ulegnie demontażowi i nie za- prof. dr hab. Piotr Świątek ${ }^{凶}$,

\section{dr Anna Z. Urbisz}

Wydział Nauk Przyrodniczych, Instytut Biologii, Biotechnologii i Ochrony Środowiska, Uniwersytet Śląski w Katowicach

https://doi.org/10.18388/pb.2021_408

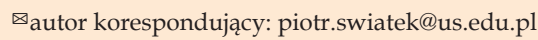

Słowa kluczowe: spermatogeneza, oogeneza, komunikacja międzykomórkowa, mostki międzykomórkowe

Skróty: ZKP - zespoły komórek płciowych, SMM - stabilne mostki międzykomórkowe 


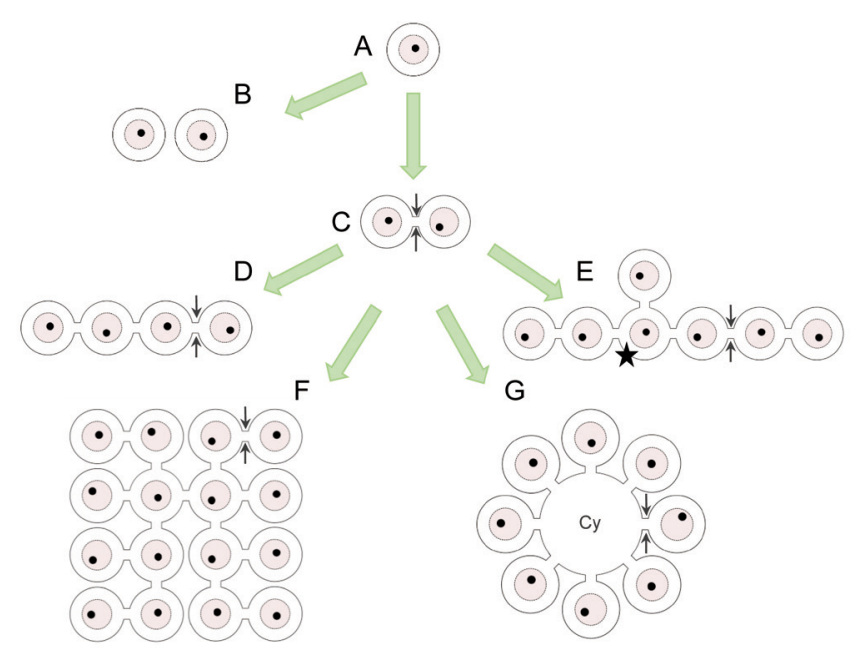

Rycina 1. Schemat przedstawia różnorodność organizacji przestrzennej zespołów komórek płciowych w czasie gametogenezy zwierząt. A) Komórka gonialna. B) U niektórych zwierząt (np. w czasie oogenezy u mięczaków) komórki płciowe dzielą się całkowicie, zespoły się nie formują. C) Praktycznie u wszystkich zwierząt w czasie spermatogenezy oraz u licznych w czasie oogenezy (np. większość owadów, pierścienice, liczne kręgowce) komórki gonialne nie dzielą się kompletnie, cytokineza jest niepełna i komórki potomne zostają połaczone kanałem cytoplazmatycznym zwanym stabilnym mostkiem międzykomórkowym (strzałki). D) Powszechnie w czasie spermatogenezy oraz w czasie oogenezy pewnych owadów, skorupiaków i wieloszczetów kolejne podziały komórek gonialnych prowadzą do powstania zespołu liniowego (łańcuch komórek). Strzałki wskazują jeden z mostków. E) U pewnych owadów i ssaków w czasie oogenezy tworzą się zespoły liniowe z rozgałęzieniami. Miejsce rozgałęzienia zespołu (komórka $\mathrm{z}$ więcej niż dwoma mostkami) zaznaczono gwiazdką, strzałki wskazują jeden z mostków. F) U licznych owadów (obie płcie) i płazów (oogeneza) tworzą się zespoły rozgałęzione. Komórki mają tyle mostków ile razy się podzieliły. Jeden z mostków wskazują strzałki. G) W czasie spermatogenezy płazińców, mięczaków i pierścienic oraz w oogenezie siodełkowców tworzą się zespoły z centralną masą cytoplazmy (cytofor, Cy). Strzałki wskazują jeden z mostków.

mknie się do końca lecz zostanie ustabilizowany przez białka cytoszkieletu (molekularne szczegóły na temat formowania się SMM zawarte są w np. [3-5]) to tworzą one obrzeża stabilnego i szerokiego kanału cytoplazmatycznego wciąż łączącego nieoddzielone do końca komórki potomne. Co ważne, takie zmodyfikowane podziały mogą odbywać się raz za razem co znacząco zwiększa liczbę połączonych komórek. W ten sposób kolejne pokolenia komórek płciowych pozostają z sobą połaczone za pomocą SMM i w takich to zespołach przechodzą one wspólnie proces gametogenezy [3-10]. Warto zaznaczyć, iż niepełne cytokinezy prowadzące do powstania SMM zachodzą także w pewnych tkankach somatycznych np. obserwowano je w czasie bruzdkowania kałamarnicy Loligo pealei czy w komórkach folikularnych obecnych w jajnikach muszki owocowej $[15,16]$. Niepełne cytokinezy są także charakterystyczne dla wielu typów komórek nowotworowych $[17,18]$, a inną odmianę niepełnej cytokinezy obserwuje się w np. prawidłowych komórkach wątroby szczura [19].

Zespoły komórek płciowych obserwuje się powszechnie w czasie spermatogenezy większości zwierząt (Ryc. 2, 3) [20-23], co więcej także wśród roślin wykazano istnienie szerokich połączeń cytoplazmatycznych pomiędzy np. komórkami macierzystymi pyłku (temat ten wykracza poza ramy opracowania, literatura dostępna w [24]). Od gąbek po ssaki (w tym człowiek), spermatogonia, spermatocyty i spermatydy nie występują indywidualnie ale właśnie są z

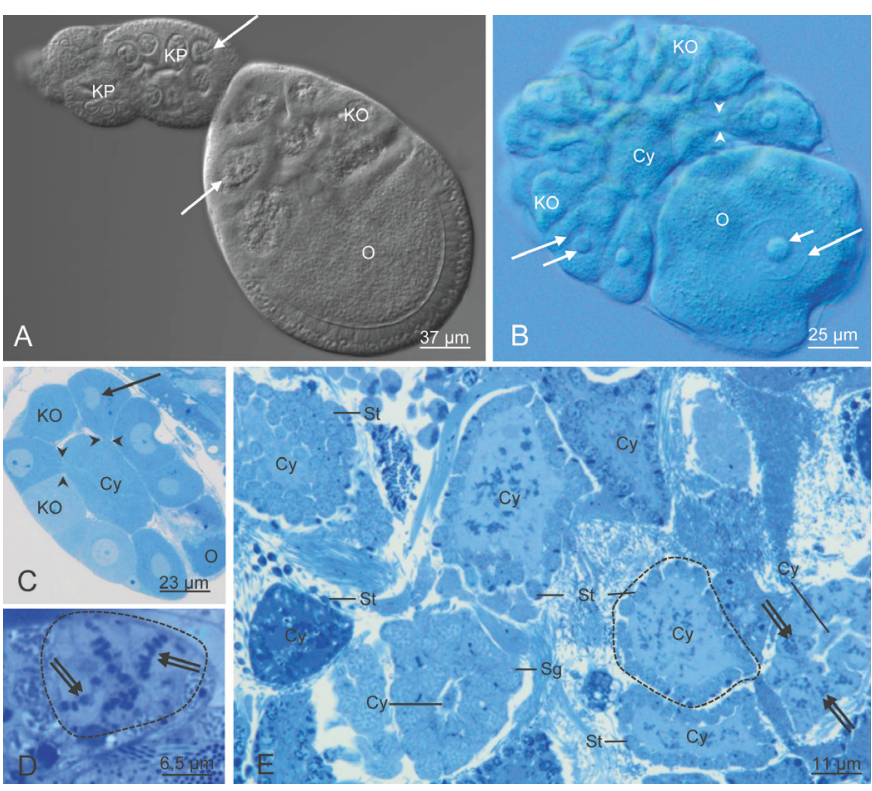

Rycina 2. Przykładowe obrazy zespołów komórkowych uzyskane za pomocą mikroskopu świetlnego. A) Fragment jajnika muszki owocowej, D. melanogaster z wyraźnie widocznymi trzema zespołami. Strzałki wskazują na jądra komórek płciowych. KP - komórki płciowe, KO - komórki odżywcze, O - oocyt. Każdy zespól liczy 16 komórek, nie wszystkie są widoczne. B) Żeński zespół komórek płciowych pobrany z jamy ciała skąposzczeta Chaetogaster diaphanus. Widoczny jest wzrastający oocyt $(\mathrm{O})$, komórki odżywcze (KO) i cytofor (Cy). Strzałki wskazuja jądra komórkowe a krótkie strzałki jaderka, groty strzałek wskazują krawędzie mostka międzykomórkowego. Zespół liczy ok. 30 komórek, większość nie jest widoczna. C) Przekrój przez żeński zespół Ch. diaphanus. Widoczne są komórki odżywcze (KO), niewielki fragment oocytu $(\mathrm{O})$ i cytofor $(\mathrm{Cy})$. Strzałka wskazuje jądro komórki odżywczej, groty strzałek wskazują krawędzie mostków międzykomórkowych. D) Fragment przekroju przez jądro skąposzczeta Grania postclitellochaeta. Przerywaną linią zaznaczony jest zespół z widocznymi czterema synchronicznie dzielącymi się spermatogoniami. Podwójne strzałki wskazują płytki metafazowe. E) Przekrój przez jądro skąposzczeta Insulodrilus bifidus. Widoczne są liczne zespoły. Wszystkie komórki w danym zespole są w tej samej fazie spermatogenezy. Jeden z zespołów łączący wydłużające się spermatydy otoczony jest linią przerywaną. Cy - cytofor, Sg - spermatogonia, St - spermatydy, podwójne strzałki wskazują synchronicznie dzielące się spermatogonia w jednym z zespołów. A-B) obrazy preparatów całościowych uzyskanych za pomoca kontrastu interferencyjnego Nomarskiego, C-E) skrawki półcienkie barwione błękitem metylenowym.

sobą połączone w ZKP. Liczne badania nad procesem oogenezy wykazały natomiast, że w linii żeńskiej obserwuje się mniej więcej równie powszechnie oba stany. Oogonia mogą dzielić się z pełną cytokinezą a oocyty są komórkami indywidualnymi (Ryc. 1) i w wielu grupach zwierząt (np. niektóre owady, pajęczaki, mięczaki, szkarłupnie, liczne pierścienice - wieloszczety) nie zaobserwowano do tej pory formowania ZKP [2,25-31]. Z drugiej strony u takich zwierząt jak liczne owady, pewne skorupiaki, wrotki, liczne nicienie, mszywioły, niesporczaki, ogonice, część pierścienic - siodełkowce, liczne kręgowce w tym ssaki wykazano, że oogonia przechodzą podziały mitotyczne, które nie kończą się pełnymi cytokinezami co prowadzi do powstania żeńskich ZKP (Ryc. 1, 2, 3) [2,6,12,25,32-36]. By skomplikować sprawę okazuje się, iż w czasie oogenezy niektórych zwierząt (niektóre owady, liczne kręgowce) oogonia tworzą zespoły, które bardzo szybko rozpadają się (ich czas trwania to często kilka dni) i później oocyty funkcjonują już wyłącznie jako komórki indywidualne $[10,25,37,38]$. Fakt istnienia takich zespołów łatwo przeoczyć, szczególnie u ssaków gdzie formowanie żeńskich zespołów odbywa się we wczesnym rozwoju zarodkowym, przed narodzinami ([10,38]; patrz rozdział: „Funkcjonowanie żeńskich ZKP”). 


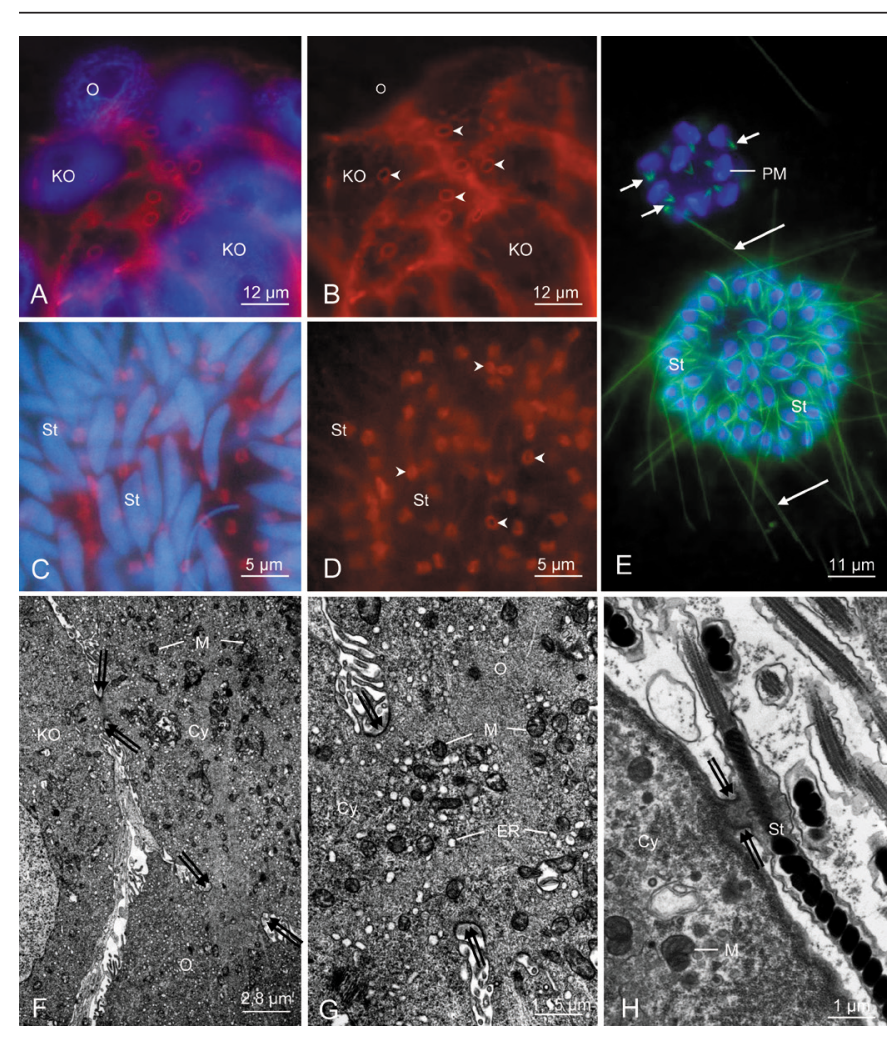

Rycina 3. A-D. Zespoły komórek płciowych pierścienic analizowane za pomocą mikroskopii fluorescencyjnej. A-B - zespół żeński wazonkowca białego, Enchytraeus albidus. Widoczne są komórki odżywcze (KO) i oocyt (O). C-D) Męski zespół złożony z wydłużających się spermatyd (St) wypreparowany z worka nasiennego dżdżownicy Lumbicus terrestris. W obu przypadkach pierwsze zdjęcie (A i C) pokazuje zespoły z widocznym DNA w jądrach komórek płciowych (barwienie odczynnikiem DAPI - niebieski sygnał) oraz widocznymi w tle mostkami międzykomórkowymi bogatymi w F-aktynę (barwienie rodaminą sprzężoną z falloidyną - czerwony sygnał). Zdjęcia B i D pokazują ten sam zespół z widocznym jedynie sygnałem czerwonym wskazującym na dużą koncentrację F-aktyny. Groty strzałek wskazują na mostki międzykomórkowe widoczne w postaci pierścieni. E) Dwa męskie zespoły L. terrestris barwione przyżyciowo odczynnikami Hoechst 33342 (znakuje DNA - niebieski sygnał) i Tubulin Tracker Green (znakuje mikrotubule - zielony sygnał). Komórki w zespole ze spermatogoniami dzielą się synchronicznie, widoczne są wrzeciona podziałowe (krótkie strzałki) płytki metafazowe (PM). Komórki drugiego zespołu to wydłużające się spermatydy (St), wyraźnie widoczne są mikrotubule zawarte $\mathrm{w}$ formujących się witkach (strzałki). F-H) Fragmenty zespołów zwizualizowane w transmisyjnym mikroskopie elektronowym. F-G) Fragmenty żeńskiego zespołu Ch. diaphanus. Widoczne są fragmenty oocytu $(\mathrm{O})$, komórki odżywczej (KO) i cytoforu (Cy) oraz mostki międzykomórkowe (ich krawędzie znaczą podwójne strzałki). W obrębie mostka widoczne są mitochondria (M) i cysterny retikulum endoplazmatycznego (ER). J - fragment jądra komórki odżywczej. H) Fragment zespołu z jądra skąposzczeta G. postclitellochaeta. Widoczna późna spermatyda (St) połączona mostkiem (podwójne strzałki) z cytoforem (Cy). M - mitochondrium.

Powszechne występowanie ZKP w czasie spermatogenezy zwierząt, obecność żeńskich zespołów w licznych grupach bezkręgowców i kręgowców, wspólny i konserwatywny mechanizm powstawania zespołów (niepełne cytokinezy) skłania naukowców do twierdzenia, że ZKP powstały bardzo wcześnie w ewolucji zwierząt wielokomórkowych i ich formowanie się należało by uznać za cechę pierwotną gametogenezy $[3,7,25]$. Jak zobaczymy dalej, w toku ewolucji ZKP, przy wykorzystaniu mechanizmu czasowej blokady cytokinezy uzyskały zaskakująco dużą różnorodność morfologiczną i funkcjonalną. Jest to kolejny przykład plastycznego wykorzystania do różnych celów mechanizmu, który prawdopodobnie powstał tylko raz w toku ewolucji.
Na zakończenie Wstępu jeszcze jedna ważna uwaga. Wiedza szczegółowa na temat molekularnych mechanizmów postawania i funkcjonowania ZKP pochodzi z badań takich gatunków modelowych jak muszka owocowa Drosophila melanogaster (przegląd w np. [3-6,8,39,40]) i mysz domowa Mus musculus $[10,13,38]$. Mniej informacji dostępnych jest na ten temat dla innych gatunków modelowych takich jak nicień Caenorhabditis elegans [34,41,42] czy żaba szponiasta Xenopus laevis [6,37]. W przypadku innych zwierząt wiedza na temat powstawania i funkcjonowania ZKP jest zwykle fragmentaryczna.

\section{FORMOWANIE I ARCHITEKTURA ZESPOŁÓW}

Jak już wspomniano, ZKP stanowią syncytia składające się z połączonych $\mathrm{w}$ jedną grupę komórek płciowych. Sposób w jaki dzielą się komórki w czasie formowania zespołu, czyli lokalizacja centrioli i co za tym idzie orientacja wrzeciona podziałowego i pierścienia zaciskowego wpływa bezpośrednio na wzajemne przestrzenne ułożenie komórek i jego architekturę (organizację przestrzenną) (Ryc. 4, 5). Dodatkowo, opis architektury zespołów komplikuje fakt, że w wielu przypadkach dochodzi do istotnych zmian ich organizacji w czasie powstawania czy funkcjonowania zespołów, takich jak np. rozpad pierwotnego zespołu na mniejsze (patrz rozdział: Funkcjonowanie żeńskich ZKP). W niniejszym opracowaniu, biorąc pod uwage różne ułożenie w przestrzeni połączonych komórek, wyróżniono cztery podstawowe typy architektoniczne ZKP: zespoły liniowe, zespoły liniowe $\mathrm{z}$ rozgałęzieniami, zespoły rozgałęzione $\mathrm{i}$ zespoły z centralną masą cytoplazmy (Ryc. 1). Inni autorzy preferują odmienną klasyfikację np. odrębnie wymieniają

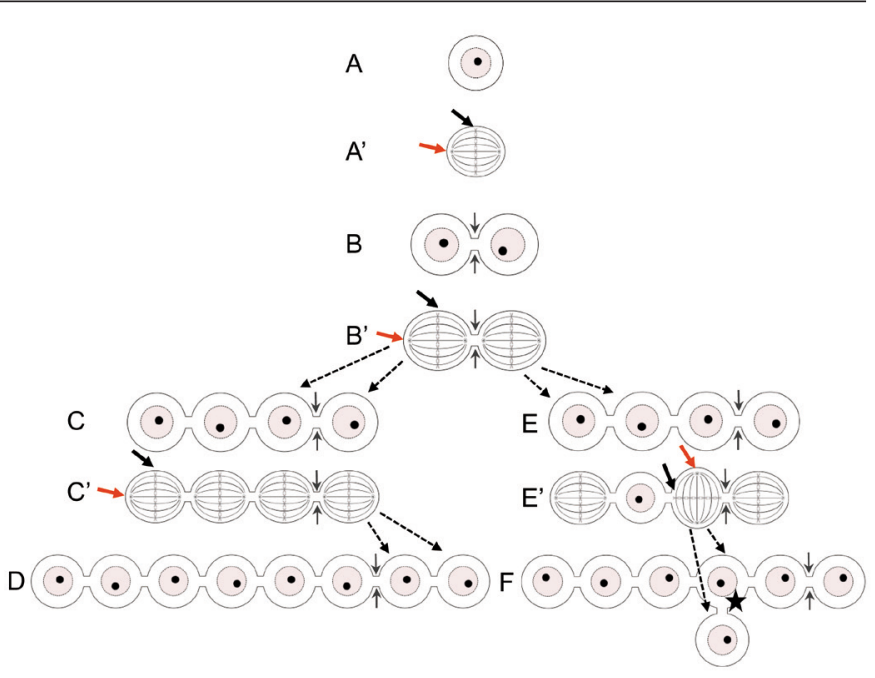

Rycina 4. Formowanie się zespołów liniowych i zespołów liniowych z rozgałęzieniami. A) komórka gonialna. A') Niepełny podział komórki gonialnej, tworzy się zespół dwukomórkowy (B). Czarne strzałki wskazują płytkę metafazową czyli płaszczyznę niepełnego podziału a strzałki czerwone jedną z centrioli. Czarne cienkie strzałki wskazują jeden z mostków. Przerywane strzałki wskazują komórki potomne jednego, wybranego podziału. B') podział zespołu dwukomórkowego. Jeśli wszystkie płaszczyzny podziałów ustawione są prostopadle do długiej osi zespołu powstaje zespół liniowy (C). C') Kolejne podziały według tego schematu prowadza do powstawania coraz dłuższego łańcucha komórek (D). W niektórych zespołach liniowych (E) nie wszystkie płaszczyzny podziałów układają się prostopadle do długiej osi zespołu, niektóre komórki mogą się także nie dzielić ( $\left.\mathrm{E}^{\prime}\right)$ i w konsekwencji tworzą się zespoły liniowe z rozgałęzieniami. Gwiazdka wskazuje na miejsce rozgałęzienia zespołu tj. komórkę z więcej niż dwoma mostkami. 
A
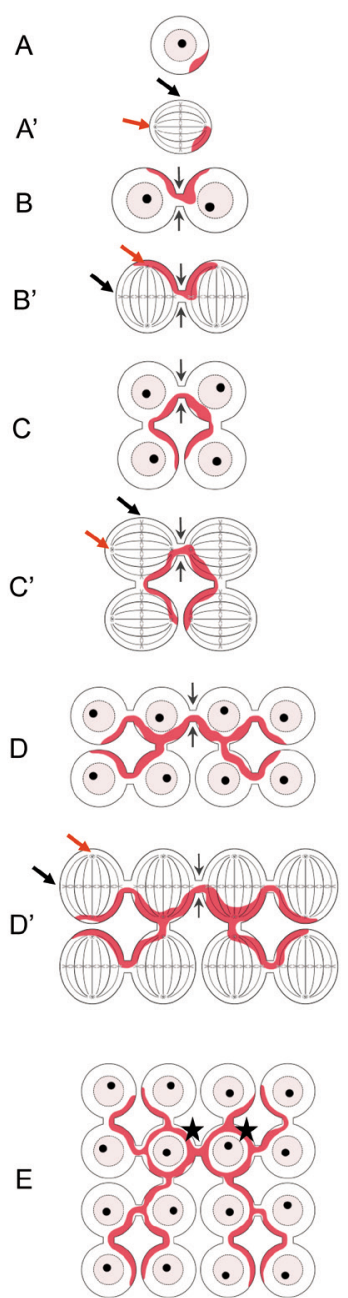
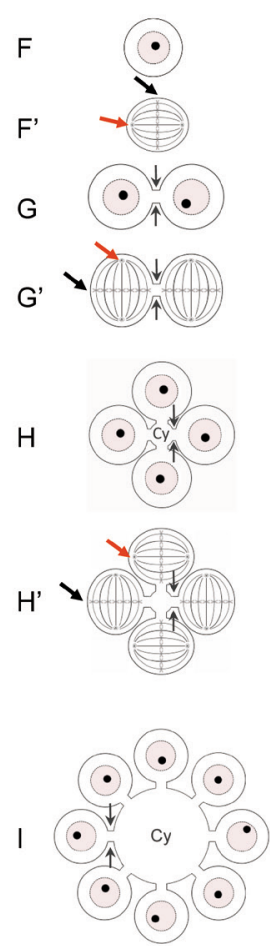

Rycina 5. Formowanie się zespołów rozgałęzionych i z centralną masą cytoplazmy. W tworzeniu zespołu rozgałęzionego (A-E) istotną funkcję pełni materiał fuzomalny (oznaczony na czerwono), do którego kotwiczy jedna z centrioli (czerwone strzałki) każdego wrzeciona podziałowego. Czarne strzałki wskazują na płaszczyznę podziału, cienkie strzałki wskazują wybrany mostek w każdym zespole. A) komórka gonialna i jej pierwszy podział (A'). B) Zespół dwukomórkowy i jego podział $\left(\mathrm{B}^{\prime}\right)$. C) Zespół czterokomórkowy i jego podział $\left(\mathrm{C}^{\prime}\right)$. D) zespól ośmiokomórkowy i jego podział (D’'). E) Zespół szesnastokomórkowy. Gwiazdkami zaznaczono dwie komórki, które przeszły cztery podziały - mają one cztery mostki. Pozostałe komórki mają także tyle mostków, ile podziałów przeszły. W czasie formowania zespołów z centralna masa cytoplazmy (F-I) centriole (czerwone strzałki) są odsunięte od istniejącego mostka (cienkie strzałki) tak, iż płaszczyzna podziału (czarne strzałki) biegnie prostopadle do środka zespołu. F i F') komórka gonialna i jej pierwszy podział. G i G') zespół dwukomórkowy i jego podział. H i H') Zespół czterokomórkowy i jego podział. Cy - zawiązek wspólnej cytoplazmy (cytofor) zlokalizowany jest w centrum zespołu. I) Zespół ośmiokomórkowy. Cytofor (Cy) zwiększa swoją objętość dzięki napływowi cytoplazmy z komórek zespołu.

zespoły dwukomórkowe, a zespoły liniowe z rozgałęzieniami traktują jako modyfikację zespołów liniowych [32,43]. Te cztery podstawowe formy ZKP znaleźć można zarówno w gonadach męskich (jądrach), jak i żeńskich (jajnikach) $[12,25]$. Ponadto odrębnie omówione zostaną przykłady zespołów, o bardziej skomplikowanej organizacji, które nie dadzą się tak prosto klasyfikować.

Zanim przedstawiony zostanie przegląd organizacji zespołów należy zwrócić uwagę na liczbę połączonych komórek. Najczęściej podziały kończące się niepełnymi mitozami są synchroniczne tj. wszystkie połączone już komórki są w tej samej fazie cyklu komórkowego (Ryc. 2D, 3E, 4, 5). Skut-

kiem tego liczba komórek w zespole wynosi zazwyczaj $2^{\text {n }}$, gdzie $\mathrm{n}$ to liczba synchronicznych podziałów (zarówno mitoz jak i mejozy) [44]. Liczba komórek w zespołach jest często specyficzna gatunkowo, a także w obrębie wyższych jednostek taksonomicznych jak rodzaj czy rodzina [12,25,44]. Często jednak zdarzają się odstępstwa od tej reguły i liczba komórek nie jest równa $2^{\mathrm{n}}$ (np. liczne owady czy niesporczaki $[25,32]$, kolejne przykłady poniżej), powodem może być asynchronia podziałów, rozpadnięcie się większego zespołu na mniejsze fragmenty czy degeneracja pojedynczych komórek [12,44].

\section{ZESPOŁY LINIOWE}

ZKP o najprostszej architekturze, łączące od dwu do nawet kilkuset komórek to zespoły gdzie komórki ułożone są liniowo jedna za drugą tworząc łańcuch (Ryc. 1, 4). Taki typ organizacji zespołu nazywamy liniowym. Należy zauważyć, że zespoły liniowe nie tworzą w gonadach łańcuchów ułożonych w linii prostej, ale zwykle są przestrzennie mocno powyginane czy poplątane. Układ komórek w formie łańcucha wynika z faktu, że wszystkie komórki posiadają po dwa mostki międzykomórkowe, za pomocą których łączą się z komórkami sąsiednimi. Jedynie komórki umiejscowione na końcach zespołu mają po jednym mostku międzykomórkowym (Ryc. 1, 4) [3,25]. Liniowy układ komórek powstaje ponieważ wrzeciona podziałowe ułożone są równolegle do długiej osi zespołu, centriole są zlokalizowane $\mathrm{w}$ pobliżu istniejących już mostków (wyjątkiem jest pierwszy podział) a pierścień zaciskowy i SMM formują się w ten sposób, że każda komórka potomna otrzymuje dwa mostki - jeden "stary" (wcześniej istniejący) a drugi to ten świeżo uformowany - „nowy” (Ryc. 4). Komórki skrajne wciąż mają jeden mostek („,nowy", Ryc. 4).

Zespoły liniowe opisano $\mathrm{w}$ czasie oogenezy $\mathrm{w}$ kilku grupach bezkręgowców takich jak pierścienice, owady czy skorupiaki. I tak, u wieloszczeta Diopatra cuprea w takich zespołach występuje 30-40 komórek [45,46], u widłogonków (owady bezskrzydłe) obserwowano maksymalnie 36 połączonych łańcuchowo komórek [47] a u skorupiaka Artemia salina uważa się, że taki łańcuch tworzony jest maksymalnie z 32 komórek [48]. Przede wszystkim jednak liniowe ZKP obserwuje się $\mathrm{w}$ czasie spermatogenezy zwierząt bezkręgowych i kręgowych, gdzie tworzą długie łańcuchy połączonych ze sobą komórek na kolejnych etapach spermatogenezy (a więc diploidalnych spermatogonii, a następnie przechodzących mejozę spermatocytów i haploidalnych spermatyd). Zespoły takie są szeroko rozpowszechnione i dobrze opisane u kręgowców (szczególnie u ssaków) i mogą zawierać setki, a nawet tysiące męskich komórek płciowych (Ryc. 6A) [3,20,49]. U ssaków, analizowanych głównie na przykładzie myszy i szczura, proces formowania zespołów obejmuje od dziewięciu do jedenastu synchronicznych podziałów spermatogoniów oraz dwa podziały mejotyczne. Proces ten teoretycznie powinien prowadzić więc do łączenia w łańcuchy tysięcy komórek i przy założeniu pełnej synchronii podziałów zespoły te powinny mieć np. 2048 komórek (dziewięć mitoz i dwa podziały mejotyczne $=2^{11}$ ). W praktyce jednak, w zespołach obserwowano do 650 komórek [3]. Podobnie u ryby danio pręgowanego (Danio rerio) spermatogonia dzielą się synchronicznie 9 razy i po dwóch 

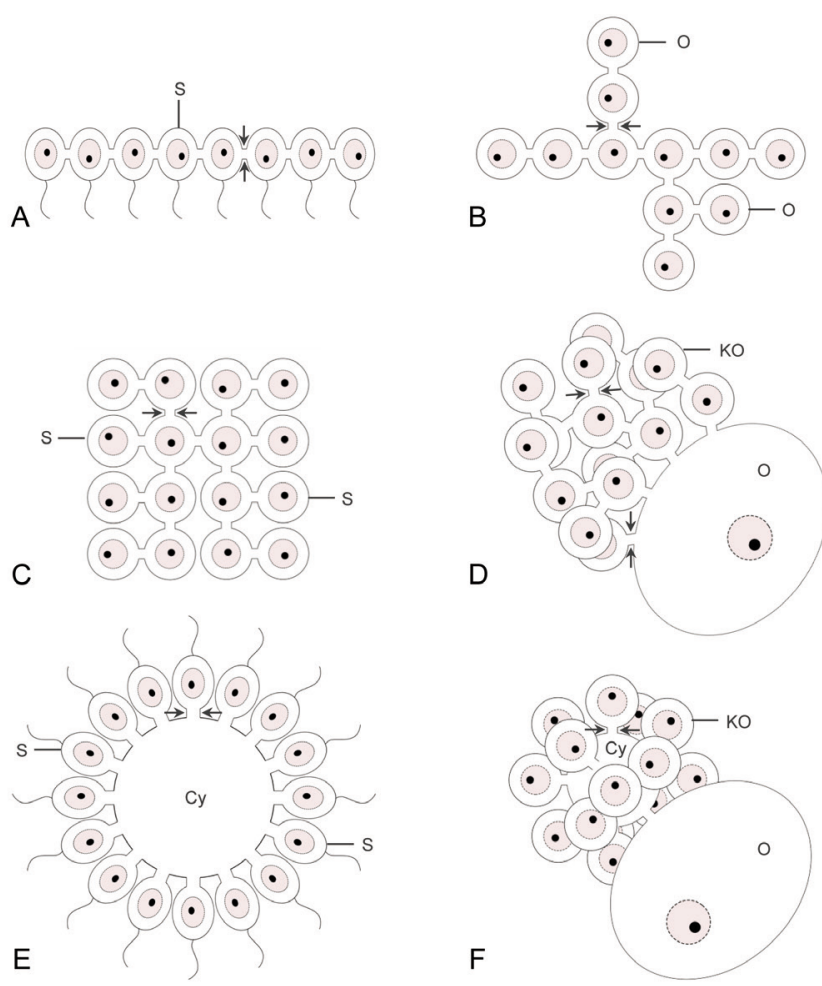

D

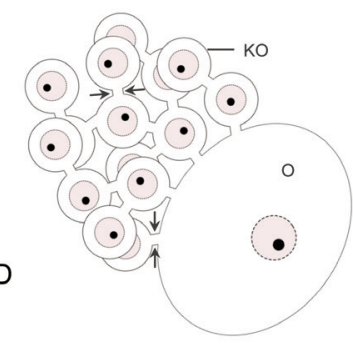

$\mathrm{F}$
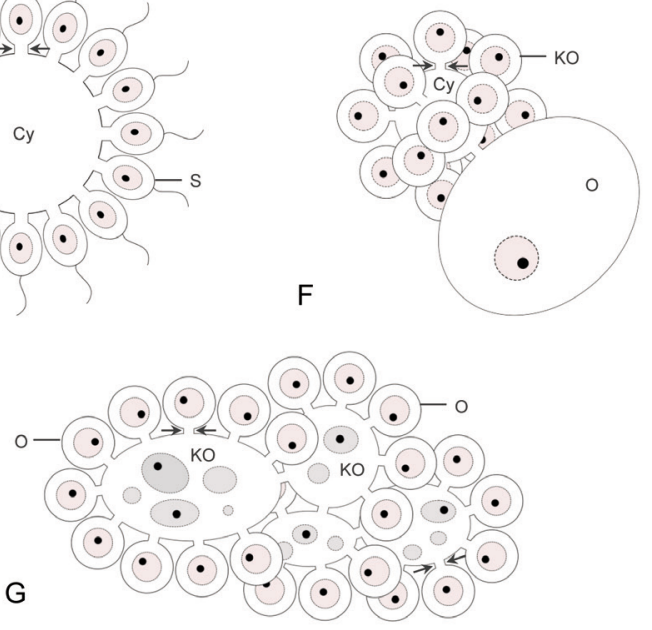

Rycina 6. Schematy organizacji męskich i żeńskich zespołów komórek płciowych u wybranych gatunków, tj. myszy (A, B), muszki owocowej (C, D), wazonkowca białego (E, F) oraz przykład zespołu o nietypowej organizacji opisanego u niesporczaka Milnesium tardigradum (G). A) Męski liniowy zespół komórek płciowych myszy z widocznymi spermatydami (S) połączonymi mostkami międzykomórkowymi (strzałki). B) Żeński zespół liniowy z rozgałęzieniami występujący u myszy, składający się z połączonych mostkami międzykomórkowymi (strzałki) oocytów (O). Uwaga: zespół taki bardzo szybko rozpada się na pojedyncze komórki, część z nich zdegeneruje, pozostałe staną się oocytami pierwotnymi. C) Męski rozgałęziony zespół muszki owocowej złożony z 16 identycznych i rozwijających się synchronicznie spermatogonii (S) połączonych mostkami międzykomórkowymi (strzałki). Uwaga: Komórki zespołu przechodzą następnie dwa podziały mejotyczne, tak więc finalnie zespół składa się z 64 spermatyd. D) Żeński rozgałęziony zespół muszki owocowej, zbudowany z jednego oocytu (O) i 15 komórek odżywczych (KO). Podobnie jak w męskim zespole liczba mostków w danej komórce (strzałki) wynika z liczby podziałów tej komórki. Uwaga: oocyt jest jedną z dwóch komórek w zespole z największą liczbą mostków (cztery). E) Męski zespół wazonkowca z widoczną centralną masą cytoplazmy - cytoforem (Cy) i synchronicznie rozwijającymi się spermatydami (S). Każda komórka połączona jest z cytoforem za pomocą pojedynczego mostka (strzałki). F) Żeński zespół wazonkowca składający się z 15 komórek odżywczych (KO) i jednego oocytu (O). Każda z komórek posiada jeden mostek międzykomórkowy (strzałki) łączący ją z centralnie położonym cytoforem (Cy). G) Żeński zespół komórek płciowych niesporczaka $M$. tardigradum z widocznymi licznymi oocytami $(\mathrm{O})$ połączonymi mostkami (strzałki) z częścią centralną zespołu. Część tą stanowią cztery obszerne wielojądrzaste komórki odżywcze (KO).

kolejnych podziałach mejotycznych zespoły powinny teoretycznie liczyć też 2048 komórek, a jak wykazały obliczenia w zespołach było ich tylko około 1360 [50]. Mniejsza liczba komórek jest skutkiem tego, że około $40 \%$ z nich ginie na drodze dwóch fal masowych apoptoz [50].

\section{ZESPOŁY LINIOWE Z ROZGAŁĘZIENIAMI}

Odmianą liniowych ZKP są tzw. zespoły liniowe z rozgałęzieniami (Ryc. 1). Układ ten powstaje na skutek takich podziałów komórek ułożonych dotychczas liniowo, w których tylko jedna z komórek potomnych otrzymuje wszystkie (dwa) dotychczasowe mostki a druga komórka potomna ma tylko jeden mostek (ten „nowy”, Ryc. 4). Taki wzór podziałów prowadzi do powstania bocznych odgałęzień. Komórki tworzące takie "miejsce rozgałęzienia” zespołu mają więcej niż dwa SMM (Ryc. 4) [51]). Zespoły liniowe z dodatkowymi rozgałęzieniami są opisywane $\mathrm{w}$ jajnikach pewnych owadów (sieciarek) i ssaków (np. myszy - patrz: Funkcjonowanie żeńskich ZKP, Ryc. 6B) i prawdopodobnie występują także we wczesnej oogenezie człowieka $[11,38,51,52]$.

\section{ZESPOEY ROZGAŁĘZIONE}

W gametogenezie wielu zwierząt, szczególnie bezkręgowych, obserwuje się z kolei tzw. rozgałęzione ZKP. W takich zespołach, poszczególne komórki łączą się z sąsiednimi komórkami za pomocą zazwyczaj więcej niż dwóch mostków międzykomórkowych (Ryc. 1). Jeśli w czasie tworzenia zespołu, podziały mitotyczne komórek zachodzą synchronicznie, a mostki są dziedziczone w ten sposób, że jedna komórka potomna otrzymuje wszystkie dotychczasowe mostki + mostek "nowy" a druga otrzymuje tylko jeden ("nowy", Ryc. 5) tak powstały zespół staje się „maksymalnie rozgałęziony". W takim zespole liczba rozgałęzień (mostków międzykomórkowych) jaką posiada dana komórka jest równa liczbie podziałów jakie przeszła [25,37,39,53,54]. Liczne badania molekularne nad mechanizmami niekompletnych podziałów generujących maksymalnie rozgałęzione zespoły zostały wykonane $\mathrm{z}$ wykorzystaniem muszki owocowej [55]. Wykazano, że taki układ jest generowany dlatego, że jedna z centrioli jest niejako „łapana” w pobliżu istniejącego już SMM (wyjątkiem jest więc pierwszy podział) poprzez oddziaływanie takich białek jak cytoplazmatyczna dyneina $\mathrm{z}$ materiałem fuzomalnym (patrz niżej). $\mathrm{W}$ konsekwencji tylko jedna z komórek potomnych (ta bliżej środka zespołu) otrzymuje wszystkie mostki, które już posiada, a nowy mostek jest wspólny dla obu komórek potomnych (Ryc. 5) $[39,53,55]$. Materiał fuzomalny to specyficzna struktura komórkowa wzbogacona w siateczkę śródplazmatyczną i białka cytoszkieletu, która pojawia się w czasie formowania zespołów rozgałęzionych. Fuzom ma kluczowe znaczenie w formowaniu tych zespołów, a w przypadku rozgałęzionych zespołów żeńskich, bierze udział w determinacji oocytu. Omówienie genezy, składu molekularnego i roli tej struktury wychodzi poza obręb pracy, a zainteresowany Czytelnik znajdzie kilka ogólnych opracowań na ten temat $[7,56,57]$.

Rozgałęzione ZKP występują $\mathrm{w}$ obu liniach płciowych licznych owadów np. motyli czy muchówek - w tym, jak już wspomniano, u muszki D. melanogaster (Ryc. 6C, D). Rozgałęzione zespoły opisano także u kręgowców, np. u żaby szponiastej $[11,25,37,39,52]$. W zespołach rozgałęzionych ogólna liczba połączonych komórek różni się w zależności od taksonu i dodatkowo często jest inna w zespołach żeńskich i męskich tego samego gatunku. Przykładowo, u motyli żeńskie ZKP zawierają 8 komórek, męskie zaś po sześciu synchronicznych mitozach, składają się z 64 komórek, a po 
mejozie w ten sposób połączonych jest 256 spermatyd $\left(2^{8}\right)$ [3,21,39]. Dla kontrastu, u niesporczaków, które także mają w linii żeńskiej zespoły rozgałęzione liczba komórek nie zawsze jest zgodna $\mathrm{z}$ regułą $2^{\mathrm{n}} \mathrm{np}$. $\mathrm{u}$ gatunku Thulinius ruffoi zespoły składają się z różnej liczby komórek oscylującej wokół 30 (maksymalnie 35) [43] natomiast u Hypsibius exemplaris w zespołach obserwowano od 21 do 27 komórek [58]. Podobna sytuacja ma miejsce u mszyc i czerwców (owady z rzędu pluskwiaków), gdzie liczba komórek w zespołach może się znacząco wahać (np. od 111 do 192), a dodatkowo u mszyc stwierdzono różną liczbę komórek w pokoleniu żyworodnym i jajorodnym $[59,60]$. U samic muszki owocowej i żaby szponiastej komórki płciowe formują zespoły o maksymalnie rozgałęzionej architekturze, składające się zawsze z 16 komórek. W przypadku muszki owocowej 15 komórek różnicuje się w komórki odżywcze, a tylko jedna w oocyt (Ryc. 6D), natomiast u żaby szponiastej wszystkie 16 komórek różnicuje się w oocyty (patrz rozdział: Funkcjonowanie żeńskich ZKP). W obu przypadkach rozgałęzione zespoły powstają na skutek czterech synchronicznych podziałów mitotycznych i wykazują charakterystyczną organizację: dwie komórki, zlokalizowane w centrum zespołu, posiadają po cztery mostki międzykomórkowe, dwie komórki posiadają po trzy mostki, cztery komórki posiadają po dwa mostki, oraz osiem komórek zlokalizowanych na obwodzie zespołu posiada po jednym mostku międzykomórkowym (zgodnie z regułą: liczba mostków = liczba podziałów, jaką przeszła dana komórka) (Ryc. 5E). U obydwu gatunków zespoły te początkowo tworzą charakterystyczny układ rozety, w którym mostki międzykomórkowe są zlokalizowane w części centralnej zespołu, a komórki ułożone są koliście wokół tej centralnej strefy - za taką organizację odpowiada materiał fuzomalny $[37,39,54,55]$. U samców D. melanogaster synchronia podziałowa utrzymywana jest przez cały czas trwania spermatogenezy, w związku z czym, cztery kolejne cykle mitoz i dwa kolejne podziały mejotyczne powodują, że finalnie męskie ZKP D. melanogaster łączą ze sobą 64 haploidalne spermatydy i dwie spermatydy mają aż sześć SMM [3,21,61].

\section{ZESPOEY Z CENTRALNĄ MASĄ CYTOPLAZMY}

Odmienna architektura ZKP występuje w obu liniach płciowych $u$ takich pierścienic jak siodełkowce i szczetnice, oraz u nicieni, roztoczy, a także $\mathrm{w}$ linii męskiej niektórych płazińców i mięczaków [12,21]. W ZKP obserwowanych w czasie gametogenezy tych zwierząt, poszczególne komórki nie są ze sobą połączone bezpośrednio, lecz grupują się wokół bezjądrowej masy cytoplazmy (Ryc. 1, 2, 3, 5, 6E, F). Ta wspólna dla całego zespołu cytoplazma (określana jako rachis $\mathrm{u}$ nicieni, cytofor u pijawek, skąposzczetów i szczetnic, lub medula/rdzeń u roztoczy), może być różnie wykształcona i mieć odmienną formę (Ryc. 2, 3) [12,62-66]. I tak centralna masa cytoplazmy może wyglądem przypominać długi i prosty rdzeń, tak jak to obserwowano u nicienia C. elegans $[33,34]$, długą i rozgałęziającą się drzewkowato strukturę, np. u skąposzczeta rurecznika mułowego Tubifex tubifex [67], lub może być niewielką i prawie kulistą masą, np. u pijawki rybiej Piscicola geometra $[68,69]$ i u skąposzczeta wazonkowca białego Enchytraeus albidus (Ryc. 6E, F) [70]. W obrębie takich zespołów, każda komórka płciowa połączona jest ze wspólną masą cytoplazmy zawsze za pomocą tylko jednego SMM (Ryc. 1, 2, 3, 5, 6E, F). Za taką architekturę zespołów znów odpowiada specyficzny układ centrioli i pierścienia zaciskowego w czasie kolejnych podziałów (Ryc. 5). W tym przypadku żadna z centrioli nie leży w pobliżu już istniejącego SMM, a bruzda podziałowa biegnie prostopadle do płaszczyzny istniejącego mostka dzieląc go na dwa mostki potomne (Ryc. 5). W konsekwencji każda komórka zespołu niezależnie od tego ile razy się podzieliła zawsze posiada tylko jeden mostek. W obszarze gdzie mostki ulegają podziałom tworzy się niewielka wspólna przestrzeń, która z czasem dzięki kierunkowemu napływowi cytoplazmy z przyłączonych komórek może znacznie powiększyć rozmiary i stać się w pełni rozwiniętą wspólną masą cytoplazmatyczną (Ryc. 5) [34,71].

Żeńskie ZKP z centralną masą cytoplazmy mogą łączyć ze sobą różną liczbę komórek, od 16 (wazonkowiec biały), około 30-60 (pijawka rybia), do nawet około 2000 (u skąposzczetów takich jak rurecznik mułowy oraz pijawek z rodziny Glossiphoniidae) [12]. W męskich ZKP wspólna masa cytoplazmatyczna również może przyjmować różny kształt, np. długiego cylindra - rachis u nicieni [64], lub mniej więcej sferycznej masy - cytofor u pierścienic (Ryc. 2E, 6E) [71-74], a sam kształt i wielkość cytoforu zazwyczaj zmieniają się w trakcie kolejnych etapów spermatogenezy. Liczba męskich komórek połączonych ze wspólną masą cytoplazmy może być różna, choć dane na ten temat są raczej fragmentaryczne. Przykładowo, u wielu siodełkowców (dżdżownice) 128 spermatyd tworzy takie zespoły co oznacza siedem synchronicznych cykli podziałowych $[21,75,76]$. U pijawek znane są też przykłady zespołów zawierających 256, 512 lub 1024 spermatydy $[72,77,78]$.

\section{ZESPOEY O INNEJ ORGANIZACJI}

Przedstawiona powyżej klasyfikacja organizacji przestrzennej ZKP jest uproszczona i nie obejmuje wielu mniej powszechnych, a bardziej skomplikowanych układów opisanych w literaturze. Zespoły takie znajdziemy m.in. u osłonicy Oikopleura dioica [79], niesporczaków Milnesium tardigradum [80] i Halechiniscus perfectus [81], czy u drapieżnych roztoczy (Astigmata) [82-85]. Pomimo tego, że zespoły takie znacząco się od siebie różnią pod względem morfologicznym, ich wspólną cechą jest obecność części syncytialnej, do której przyłączone są rozwijające się oocyty. Te syncytialne części przybierają jednak różnorodne kształty i organizację przestrzenną. Istotne różnice są widoczne również w funkcjonowaniu takich zespołów. Przykładowo, u niesporczaka M. tardigradum część syncytialną każdego zespołu tworzą cztery wielojądrzaste komórki (liczba jąder komórkowych w ich obrębie waha się między 12 a 74), które tworzą "rdzeń" do którego przyłączone są liczne oocyty (od 12 do 52, Ryc. 6G) [80]. Również same komórki wielojądrzaste łączą się ze sobą mostkami międzykomórkowymi (Ryc. 6G) [32,80]. Z kolei u osłonicy $O$. dioica zespół stanowi jedno syncytium, zawierające około 100 jąder komórkowych zatopionych we wspólnej cytoplazmie. Jądra komórkowe tworzą tutaj dwie populacje: jądra poliploidalne i jądra mejotyczne, występujące $\mathrm{w}$ równych proporcjach. Błony komórkowe oddzielające poszczególne jądra mejotyczne od reszty syncytium pojawiają się dopiero później, wraz z postępem oogenezy. W efekcie tego, część z komórek mejotycznych rozwija się 
w oocyty, które pozostają w kontakcie syncytium, dzięki utworzonym mostkom międzykomórkowym. Syncytium wraz z jądrami poliploidalnymi pełni tu funkcję komórek odżywczych [79,86,87].

\section{FUNKCJONOWANIE ŻEŃSKICH ZKP}

Niezależnie od architektury, funkcjonowanie żeńskich ZKP jest skorelowane $\mathrm{z}$ losami rozwojowymi komórek płciowych, a tym samym z typem oogenezy (panoistyczna vs. meroistyczna). W przypadku oogenezy panoistycznej (z gr. pan $=$ wszystko + oon $=$ jajo) wszystkie oogonia (oprócz degenerujących) różnicują się w oocyty. Ponadto często nie obserwuje się w ogóle formowania zespołów (np. liczne stawonogi czy mięczaki) $[2,25,26,28]$. W nielicznych przypadkach np. u owadów z rzędu widelnic [88] czy żaby szponiastej [37] zespoły formują się we wczesnej oogenezie (przed mejozą) ale w miarę postępu oogenezy rozpadają się szybko na indywidualne komórki, z których każda rozwija się dalej w oocyt. Tam gdzie żeńskie ZKP występują dłużej, do czasu zaawansowanej oogenezy wykazano, że stają się one spolaryzowane. Polaryzacja ZKP polega na kierunkowym transporcie makrocząsteczek i organelli poprzez mostki międzykomórkowe $\mathrm{z}$ niektórych komórek w zespole do oocytów czyli przyszłych komórek jajowych. Taki spolaryzowany transfer ma na celu wspieranie rozwoju wybranych komórek i przyspieszenie oogenezy (patrz rozdział: Dlaczego komórki płciowe funkcjonują w zespołach?). Polaryzacja wiąże się więc z różnicowaniem się komórek płciowych w obrębie danego zespołu na dwie kategorie o odmiennych losach: oocyty mające potencjał do rozwoju w komórki jajowe, oraz komórki pełniące funkcje wspierające rozwój tych pierwszych zwane komórkami odżywczymi bądź trofocytami $[89,90]$. Często zróżnicowaniu losów komórkowych towarzyszy także wyraźne zróżnicowanie morfologiczne i funkcjonalne komórek a taką oogenezę określa się jako meroistyczną $(\mathrm{z}$ gr. meros $=$ część + oon $=$ jajo $)$. W takich zespołach oocyty kontynuują oogenezę, gromadzą materiały zapasowe, otaczane są osłonami jajowymi i wchodzą w kolejne etapy mejozy, a komórki odżywcze nie kontynuują mejozy, nie rosną tak znacząco jak oocyty, ale za to są często komórkami poliploidalnymi. Główną funkcją komórek odżywczych jest bowiem synteza, a następnie transport makrocząsteczek i organelli do oocytu (bądź oocytów), podczas gdy jądro komórkowe oocytu pozostaje często nieaktywne transkrypcyjnie [25,51,54,91-93]. Poliploidyzacja jąder komórkowych w komórkach odżywczych jest charakterystyczna dla wielu owadów, przykładowo u D. melanogaster materiał genetyczny w komórkach odżywczych jest zwielokrotniany 12 razy, a u motyli 16 razy [25]. Z drugiej strony, $\mathrm{u}$ innych zwierząt, np. u wspomnianego wcześniej wazonkowca białego, komórki odżywcze nie ulegają poliploidyzacji. U tego gatunku, ploidia komórek występuje na poziomie $4 \mathrm{C}$, co jest wynikiem replikacji DNA w fazie $S$ cyklu komórkowego, zachodzącej przed rozpoczęciem mejozy (tutaj wszystkie komórki w 16-komórkowym zespole rozpoczynają profazę I mejozy, po czym $15 \mathrm{z}$ nich powraca do interfazy, a tylko jedna - oocyt kontynuuje mejozę) [70].

Niezależnie od stopnia wyspecjalizowania komórek odżywczych, zwykle obserwuje się transfer ich organelli (tj. mitochondria, rybosomy, aparaty Golgiego, siateczka śród- plazmatyczna, centrosomy) i takich makrocząsteczek jak mRNA (na bazie których następuje synteza odpowiednich białek już w nowym organizmie, jest to tzw. matczyna informacja rozwojowa) do oocytów (lub oocytu) [25,94]. Liczne badania morfologiczne, molekularne i eksperymentalne potwierdziły istnienie takiego jednokierunkowego transferu w przypadku oogenezy meroistycznej [6-8,13,25,92]. W przypadku D. melanogaster, gdzie w każdym zespole żeńskim 15 komórek odżywczych przekazuje cytoplazmę wraz $\mathrm{z}$ zawartością do jednego oocytu transfer ten zachodzi w dwóch etapach: początkowo jest powolny i selektywny; w wyniku tego zachodzi powolny ruch cytoplazmy i w oocytach gromadzi się wiele różnych mRNA np. bicoid, oskar i gurken. W kolejnym etapie dochodzi do szybkiego, intensywnego i nieselektywnego transferu, w wyniku którego praktycznie cała cytoplazma komórek odżywczych zostaje niejako „przelana” do oocytu [95]. U muszki owocowej poznano dokładnie mechanizmy molekularne odpowiedzialne za powstanie i funkcjonowanie takiego spolaryzowanego transferu, w tym wykazano tu szczególną rolę cytoszkieletu mikrotubularnego i aktynowego $[7,33,40,95,96]$. Co ciekawe, ostanie badania nad formowaniem żeńskich ZKP muszki owocowej wykazały, że pewne białka (w tym wypadku cyklino-zależny inhibitor kinaz) mogą być przekazywane w drugą stronę: z oocytu do komórek odżywczych. Okazało się, że u muszki owocowej to oocyt reguluje wzrost komórek odżywczych [97].

Cechą charakterystyczną oogenezy meroistycznej jest fakt, że komórki odżywcze po spełnieniu swoich funkcji zostają wyeliminowane $[45,54,90,94,98-101]$. Proces eliminacji związany jest najczęściej z programowaną śmiercią komórkową - apoptozą, a pozostałości komórek (ciała resztkowe) są następnie usuwane na drodze fagocytozy przez komórki somatyczne [89,98,102,103]. Niektóre obserwacje wskazują także na inny możliwy mechanizm eliminacji komórek odżywczych. Przykładowo u wazonkowca białego rosnący oocyt otacza swoją grupę komórek odżywczych, które prawdopodobnie są przez niego następnie wchłaniane, w tym przypadku nie zaobserwowano apoptozy komórek odżywczych [70,104]. Natomiast u stułbi $[105,106]$, po transferze cytoplazmy komórki odżywcze ulegają apoptozie, lecz ich pozostałości są fagocytowane przez sam oocyt. Co ciekawe, rozwijające się w ten sposób liczne oocyty ulegają fuzji, $\mathrm{w}$ efekcie czego pod koniec oogenezy powstaje $\mathrm{z}$ nich jeden ogromny oocyt [105-107].

Poza ,typowymi" meroistycznymi przykładami oogenezy, w literaturze znane są też opisy funkcjonowania zespołów, które do tej pory nie klasyfikowano jako meroistyczne, ponieważ nie stwierdzono występowania morfologicznie odmiennych komórek odżywczych. Dokładne analizy pozwoliły jednak wykazać tutaj także dwie populacje komórek o odmiennych losach. Do takich zwierząt należy nicień C. elegans i mysz $[33,52]$. W obu przypadkach ZKP składają się wyłącznie z oocytów (wszystkie komórki wchodzą w profazę mejozy), jednakże tylko część z nich będzie kontynuować oogenezę i rozwijać się w gamety, przy wsparciu ze strony pozostałych, siostrzanych komórek. Udowodniono eksperymentalnie, że w jajniku C. elegans występuje przepływ cytoplazmy wraz z jej zawartością w kierunku wzrastających oocytów. Cytoplazma ta pochodzi głównie 
z komórek rozrodczych będących we wcześniejszym stadium mejozy (pachytenie) i za pośrednictwem wspólnego dla zespołu rdzenia cytoplazmatycznego (rachis), kierowana jest do wybranych komórek. Ponieważ badacze sugerują, że większość lub wszystkie komórki rozrodcze będące w pachytenie mejozy mają potencjał do różnicowania się w oocyty, wydaje się, że w czasie oogenezy C. elegans komórki płciowe czasowo funkcjonują jako komórki wspierające rozwój "starszych" komórek siostrzanych, zanim same wejdą na tą samą drogę rozwoju i staną się oocytami [33]. Z drugiej strony wykazano, że około połowa żeńskich komórek rozrodczych u tego nicienia umiera w wyniku apoptozy pod koniec pachytenu [102]. W takim przypadku te umierające komórki funkcjonują wyłącznie jako komórki wspierające rozwój oocytów (czyli komórki odżywcze) i nie stają się gametami. Podobna sytuacja ma miejsce u myszy. Mysie ZKP składają się z około 30 połączonych oocytów, jednak tylko część $\mathrm{z}$ nich rozwija się $\mathrm{w}$ funkcjonalne gamety (najprawdopodobniej są to komórki połączone największą liczbą mostków międzykomórkowych z komórkami siostrzanymi) [38]. Komórki te otrzymują od swoich siostrzanych komórek, za pośrednictwem SMM, cytoplazmę wraz z organellami takimi jak mitochondria, siateczka śródplazmatyczna, aparaty Golgiego i rybosomy. Po takim kierunkowym transferze, oocyty-dawcy (czyli komórki odżywcze) giną na drodze apoptozy, a cały ZKP rozpada się na pojedyncze komórki (oocyty-biorcy), które od tego momentu rozwijają się indywidualnie [7,38]. Opisane procesy zachodzą bardzo wcześnie, bo już w okresie życia płodowego, a sam transfer i następujący po nim rozpad mysich ZKP zachodzi bardzo szybko (20.5-22.5 dzień po zapłodnieniu), co znacznie utrudnia badania [108]. Przez wiele lat powstawanie i funkcjonowanie ZKP u myszy i innych ssaków pozostawało zagadką i naukowcy byli zdania, że oocyty od początku rozwijają się wyłącznie samodzielnie, a jeśli już obserwowano mostki i ZKP to często uważano to za zjawisko krótkotrwałe i bez znaczenia biologicznego [3,13,38,108].

\section{FUNKCJONOWANIE MĘSKICH ZKP}

W spermatogenezie zarówno podziały mitotyczne, jak i mejoza zachodzą synchronicznie i symetrycznie, prowadząc do powstania identycznych morfologicznie i funkcjonalnie komórek potomnych (Ryc. 2, 3). Oznacza to, że wszystkie połączone $\mathrm{w}$ zespole komórki mają potencjał do rozwoju w plemniki [22]. Męskie ZKP funkcjonują praktycznie przez cały czas trwania spermatogenezy, łącząc komórki na różnych etapach, poczynając od spermatogonii po spermatydy (Ryc. 2E, 6). Uważa się, że uwspólnianie cytoplazmy męskich komórek płciowych powoduje ich synchroniczny rozwój i ma funkcje regulacyjne. Zważywszy na to, że w czasie spermatogenezy wszystkie komórki mają potencjał by stać się funkcjonalnymi gametami, oraz na dużą liczbę takich komórek w zespołach, połączenie komórek w jedno syncytium pozwala zintensyfikować proces formowania plemników [3,4,11,24,109] (patrz rozdział: Dlaczego komórki płciowe funkcjonują w zespołach?).

Jedną z grup, u których spermatogeneza została dokładnie poznana są ssaki. U ssaków męskie komórki płciowe rozwijają się w obrębie nabłonka plemnikotwórczego kanalików jąder, występując w określonym porządku prze- strzennym, w którym najmłodsze stadia (spermatogonia) ułożone są u podstawy kanalika, a kolejne generacje komórek (spermatocyty i spermatydy) ułożone są w kierun$\mathrm{ku}$ jego światła. Umożliwia to następnie uwolnienie $\mathrm{z}$ nabłonka plemnikotwórczego powstających ze spermatyd plemników i ich przedostanie się do światła kanalików. Jak już wspomniano, wszystkie komórki płciowe powstające w trakcie kolejnych cykli podziałowych, pozostają ze sobą połączone SMM tworząc długie liniowe ZKP [7,22,110]. Jedynie pierwsze pokolenie spermatogonii określane jako As (z ang. single) to komórki pojedyncze, które funkcjonują jako komórki macierzyste spermatogonii utrzymując pulę męskich komórek płciowych na właściwym poziomie. Kolejne podziały mitotyczne spermatogonii As prowadzą do powstania pokolenia spermatogonii Ap (z ang. pair) połączonych w pary mostkiem międzykomórkowym, a następnie liniowych zespołów połączonych spermatogonii Aal (z ang. aligned). Komórki te przechodzą kolejno dwa (u chomika chińskiego) lub trzy (u myszy i szczura) synchroniczne cykle mitoz, tworząc pokolenia A1-A4 i prowadząc do powstania długich łańcuchów spermatogonii. Następne synchroniczne podziały spermatogonii A4 dają kolejno pokolenia spermatogonii In (z ang. intermediate), spermatogonii B i spermatocytów. Powstanie spermatocytów kończy proces namnażania mitotycznego komórek w zespole i wszystkie powstałe spermatocyty wchodzą w podziały mejotyczne. Po dwóch podziałach mejotycznych, liczba komórek w zespole (spermatyd) zwiększa się czterokrotnie. Warto dodać, że u naczelnych, spermatogonia określane są inaczej niż u pozostałych ssaków, jako Ad (z ang. dark) będące zarazem komórkami macierzystymi i Ap (z ang. pale) będące odpowiednikiem Aal innych ssaków. W wyniku podziałów spermatogonii Ap powstają spermatogonia B, które kontynuują proces spermatogenezy i rozpoczynają podziały mejotyczne $[7,110]$.

W przypadku ZKP ze wspólną masą cytoplazmy, spermatogeneza również zachodzi synchronicznie. W związku z tym, wszystkie komórki w obrębie ZKP znajdują się na tym samym etapie spermatogenezy, a więc dany ZKP zawiera wyłącznie jedno pokolenie komórek płciowych (spermatogonia, spermatocyty, spermatydy i formujące się plemniki) (Ryc. 2E, 3E). Wspólna cytoplazma znajdująca się $\mathrm{W}$ centrum ZKP pełni w czasie spermatogenezy rolę podporową i odżywczą [21]. Dodatkowo, jak wykazano na przykładzie dżdżownic, cytofor będący centralną częścią zespołu nie tylko pośredniczy w wymianie informacji między komórkami, lecz może także służyć jako „śmietnik”, poprzez magazynowanie składników komórkowych, które wraz z postępem spermatogenezy stają się zbędne, np. mitochondria, które nie wchodzą w skład wstawki plemnika [111].

\section{DLACZEGO KOMÓRKI PŁCIOWE FUNKCJONUJĄ W ZESPOŁACH?}

Jakie korzyści (przewagę) przynosi komórkom płciowym stan umożliwiający $\mathrm{w}$ miarę swobodną wzajemną lub kierunkową wymianę cytoplazmy? Odpowiedź na to ważne pytanie już częściowo padła w poprzednim rozdziale przy omawianiu funkcjonowania zespołów. Literatura przedmiotu przedstawia tutaj jednak wiele różnych analiz i hipotez, warto więc ten temat omówić osobno. Ponieważ 
ZKP linii męskiej i żeńskiej funkcjonują inaczej to należy rozpatrywać te korzyści odrębnie dla każdej płci.

Bardzo często podkreśla się, szczególnie w przypadku męskich ZKP, fakt, iż połączone komórki różnicują się $\mathrm{w}$ pełnej synchronii [3-8,10,22]. Ostanie badania eksperymentalne myszy, gdzie badano mutanty, u których nie formują się SMM wykazały, że choć spermatogonia mogą się dzielić w kolejne pokolenia to synchronia tych podziałów jest zaburzona [112]. Powszechnie uważa się, że taka wspólna kontrola wchodzenia w kolejne fazy cyklu komórkowego ma ułatwić komórkom wejście i przejście przez mejozę. W linii żeńskiej synchronia podziałów także występuje powszechnie (choć znamy przypadki jej zaburzenia, patrz rozdział: Formowanie i architektura zespołów) ale i tu uważa się, że formowanie zespołów ułatwia wejście oocytów w mejozę [11], co ostatnio potwierdziły również badania eksperymentalne [113]. Przy czym należy zauważyć, iż w przypadku linii żeńskiej synchronia podziałów komórkowych jest krótkotrwała i dotyczy głownie oogoniów. Jak już wspomniano często zdarza się (np. mysz), że zespoły rozpadają się zanim komórki wejdą w mejozę, lub nie wszystkie połączone komórki rozpoczynają mejozę (muszka owocowa). Jak wykazały badania nad muszką owocową, za synchronię cyklu komórkowego w obrębie zespołu odpowiada wspomniana już specyficzna struktura zwana fuzomem, a konkretnie różnego rodzaju cykliny z nią związane $[7,114]$. $Z$ drugiej strony fuzom nie był obserwowany w ssaczych ZKP i nie wiadomo jaki mechanizm zapewnia synchronię $\mathrm{w}$ tym przypadku $[7,10]$.

W linii męskiej ZKP obserwuje się zazwyczaj od stadium spermatogonii aż do późnych spermatyd, czyli SMM łączą także komórki haploidalne [20-23]. Badania molekularne wykazały, iż następuje wzajemna wymiana produktów genowych pomiędzy haploidalnymi spermatydami co ma uzupełnić oczywiste dla takich komórek braki, bo np. spermatydy zawierające chromosom $X$ wymieniają swoje produkty $\mathrm{z}$ tymi które mają chromosom $\mathrm{Y}$ i vice versa $[7,9,115]$. Taka wzajemna wymiana i uzupełnienie produktów genowych zapewnia prawidłową transformację spermatyd $\mathrm{w}$ plemniki, i ten argument podaje się jako główną przyczynę istnienia męskich ZKP [7,9,22,24,115]. O tym jak ważne jest istnienie ZKP w linii męskiej świadczy fakt, iż zaburzenia w formowaniu SMM czy ich kompletny brak prowadzi do sterylności, co wykazano zarówno w przypadku muszki owocowej [116] jak i myszy [117]. Należy zauważyć, iż potrzeba bezpośredniej łączności pomiędzy haploidalnymi spermatydami nie wyjaśnia dlaczego wiele pokoleń diploidalnych spermatogonii jest także połączonych w zespoły. Przykłady gdzie spermatogonia są indywidualnymi komórkami, a tylko komórki przechodzące mejozę (czyli spermatocyty) i później spermatydy są połączone mostkami (czyli tworzą tetrady spermatyd), są nieliczne np. liczne wieloszczety $\mathrm{z}$ taksonów Sabellinae i Serpulidae [118].

Kolejne światło, na możliwe funkcje ZKP w linii męskiej, rzucają badania nad wpływem uszkodzeń DNA w jądrach D. melanogaster $[7,119]$. Badania te jednoznacznie wykazały, że jeśli uszkodzi się DNA w pojedynczych komórkach w zespole ze spermatogoniami (zespoły takie liczą 16 komórek), to wszystkie komórki zespołu umierają. Jeśli jednak taki eksperyment przeprowadzimy u mutantów, które mają niefunkcjonalny fuzom, to programowaną śmierć przejdą wyłącznie uszkodzone komórki, a reszta komórek zespołu przeżyje [7,119]. Wyciągnąć można z tego eksperymentu co najmniej dwa wnioski: 1) fuzom pośredniczy w przekazywaniu sygnałów śmierci do wszystkich połączonych komórek i 2) komórki linii płciowej są niejako "przeczulone” na uszkodzenia DNA, skoro jego uszkodzenie w jednej lub kilku komórkach skutkuje śmiercią całego zespołu, czyli także komórek gdzie prawdopodobnie DNA było nieuszkodzone. Ten drugi fakt jest znany od dawna i wiąże się go z większą ochroną gamet przed uszkodzeniami DNA [7,120]. Łączenie się komórek płciowych w zespoły (przynajmniej te męskie), zwiększa więc ich ogólną wrażliwość na uszkodzenia DNA, nawet kosztem eliminacji komórek nieuszkodzonych. Z kolei niedawne badania nad charakterystyką białek wchodzących w skład SMM w męskiej linii płciowej myszy wykazały, że mogą one wiązać RNA, co sugeruje rolę mostków w kontroli epigenetycznej spermatogenezy [121].

W linii żeńskiej istnienie wspólnoty cytoplazmatycznej w obrębie zespołu także umożliwia transfer cytoplazmy ale, w odróżnieniu od linii męskiej jest to zwykle transfer jednokierunkowy (spolaryzowany). Transfer ten odbywa się wzdłuż osi: komórki odżywcze - oocyt (bądź oocyty) i $\mathrm{w}$ pełnej formie jest on obserwowany w oogenezie meroistycznej jak to już opisano wcześniej [6-8,13,25,92]. Także u ssaków (mysz, królik) wykazano jednokierunkowy transfer podczas krótkiego czasu, w którym komórki są z sobą połączone [7,38,52]. Finalnie, komórki odżywcze (a także komórki pełniące funkcje komórek odżywczych w jajnikach nicieni czy ssaków) po przekazaniu oocytom swojej cytoplazmy, są eliminowane z ZKP na drodze programowanej śmierci komórkowej $[89,98,108]$. W związku z tym tylko komórki "biorcy” czyli oocyty mają potencjał by przeżyć i przekształcić się w funkcjonalne gamety. Przyjmuje się, że istnienie takiej transmisji („mechanizmu odżywczego") znacznie przyśpiesza proces oogenezy, a jego istnienie podaje się jako główną korzyść istnienia ZKP w linii żeńskiej $[7,10,11,13,25,38,52]$. Jak ważne jest prawidłowe funkcjonowanie połączonych komórek w czasie oogenezy meroistycznej świadczy fakt, iż u muszki owocowej zaburzenia w uformowaniu prawidłowego transferu na osi komórki odżywcze-oocyt oraz defekty wpływające na prawidłowe przekazywanie cytoplazmy do oocytu, prowadzą do kompletnej sterylności lub produkcji niepełnowartościowych oocytów [40]. Co zaskakujące, u myszy eksperymentalne zaburzenie formowania zespołów w jajnikach poprzez blokowanie formowania SMM nie doprowadziło do sterylności samic [122]. Wyniki te sugerowały, iż u myszy w linii żeńskiej formowanie zespołów nie ma istotnego znaczenia dla płodności, a istnienie zespołów tłumaczono podobnie jak tłumaczy się występowanie narządów szczątkowych - są w linii żeńskiej bo są niezbędne w linii męskiej ale ich funkcjonowanie nie ma znaczenia dla płodności samic [3,122]. Kolejne badania pozwoliły na przynajmniej częściowe wyjaśnienie tego zjawiska [38]. Jak wcześniej wspomniano, dziś wiemy, iż w mysich żeńskich zespołach występuje transfer organelli, który jest istotny dla selekcji przyszłych oocytów. Co bardzo interesujące transfer pomiędzy komórkami może odbywać się dwoma drogami: poprzez SMM oraz poprzez obszerne otwory w błonach komórkowych sąsiadujących komórek 
zwanych w oryginale "szczelinami” (z ang. gaps) [38]. Szczeliny te nie mają charakterystycznej dla SMM elektronowo gęstej okładziny, a o ich postawaniu i funkcjonownaiu nie ma danych. Transfer organelli przez te szczeliny tłumaczy dlaczego, przy eksperymentalnym zablokowaniu formowania klasycznych SMM, samice nadal są płodne [38]. Ostatnio potwierdzono, że u myszy w przypadku gdy nie formują się SMM, oogeneza może zachodzić (komórki w zespołach mają łaczność cytoplazmatyczną poprzez "szczeliny”), ale zespoły takie są dużo mniejsze i oocyty pierwotne mają małe rozmiary [123].

Poza tą mocno już ugruntowaną wiedzą na temat korzyści płynących z grupowego funkcjonowania komórek płciowych w oogenezie, $w$ literaturze dyskutuje się i inne koncepcje. Dla przykładu pewni Autorzy wskazują, że np. uszkodzone mitochondria mogą być przekazywane do komórek, które później są eliminowane (czyli klasyczne komórki odżywcze i komórki funkcjonujące jak komórki odżywcze np. u myszy) i ten sposób następuje oczyszczenie oocytów z wadliwych organelli, co znacznie poprawia ich jakość i tym samym jakość przyszłego zarodka [108,124]. Wskazuje się także na fakt, iż wymiana RNA, a w szczególności akumulacja pewnych frakcji RNA takich jak piRNA (z and. piwi-interacting RNA) w przyszłych oocytach ma duże znaczenie dla blokowania transpozonów na dalszych etapach oogenezy [38]. Kolejne badania wskazują, że istnienie mostków międzykomórkowych i lokalizowanie $\mathrm{w}$ ich pobliżu centrioli czy innych akumulacji organelli (znanych pod nazwą ciała Balbianiego) powoduje, że oocyty stają się asymetryczne i przynajmniej chwilowo spolaryzowane. Według Kloc i współpracowników [125] taka wczesna polaryzacja oocytów jest konserwatywną cechą oogenezy wszystkich zwierząt. Inne obserwacje, które wykazały, że np. u mutantów muszki owocowej mających zablokowane funkcjonowanie genów odpowiedzialnych za determinacje płci (np. Sex-lethal) zostaje zakłócone formowanie ZKP, a u myszy aktywność genu Dax-1 (jednego z genów regulujących powstanie płci) zachodzi $\mathrm{w}$ czasie formowania ZKP sugerują, że powstanie zespołów może być także związane z jakimś konserwatywnym mechanizmem determinacji płci [11]. Inne sugerowane funkcje ZKP to np. hamowanie mitoz komórek gonialnych, tak by ograniczeniu później uległa liczba komórek wchodzących w mejozę, czy hamowanie mobilności komórek płciowych [10].

\section{PODSUMOWANIE I PERSPEKTYWY}

Intensywne badania nad ZKP cały czas trwają i można tu wyróżnić dwa kierunki. W jednym, przy użyciu technik mikroskopowych opisuje się wciąż nowe ZKP zwracając szczególną uwagę na ich organizację przestrzenną i funkcjonowanie, przykładem mogą badania nad niesporczakami i pierścienicami $[12,32]$. Drugi kierunek badań dotyczy gatunków modelowych (muszka owocowa, mysz, C. elegans), gdzie obok technik mikroskopowych naukowcy posługują się nowoczesnymi technikami molekularnymi aby poznać mechanizmy funkcjonowania zespołów (badania takie są licznie cytowane w niniejszym opracowaniu). Co zaskakujące, także $w$ przypadku ZKP w organizmach modelowych odkrywane są wciąż nowe i istotne fakty. I tak ostatnio Ali-Murthy i współpracownicy [126] wykazali, że w żeńskich
ZKP D. melanogaster dochodzi do fuzji dwóch komórek odżywczych z oocytem. W konsekwencji jądra tych dwóch komórek wnikają do oocytu, gdzie następnie degenerują. Pomimo ponad 60 lat intensywnych badań żeńskich ZKP muszki owocowej fakt ten nie był dotychczas opisany.

Wydawać się może, że badania nad ZKP, oprócz waloru poznawczego, nie mają wpływu na nasz życie. Nieprawda. Zrozumienie jak funkcjonują ZKP, zwłaszcza u ssaków, ma duży potencjał dla nauk medycznych zajmujących się ludzką płodnością. Dzięki tym badaniom np. lepiej rozumiemy jakie mechanizmy leżą u podstaw masowego obumierania oocytów jeszcze $\mathrm{w}$ czasie życia płodowego. Wiadomo, że zaburzenia w czasie tego procesu mogą powodować takie przypadłości jak pierwotny brak miesiączki czy przedwczesną niewydolność jajników [127]. Wydaje się, że badania podstawowe skierowane na poznanie roli ZKP $w$ tych procesach pomogą opracować odpowiednią diagnostykę i procedury leczenia. Kolejny przykład: niedawno wykazano, że u myszy aby powstały mostki międzykomórkowe niezbędne jest białko TEX14, a jego brak w linii męskiej powoduje sterylność [117]. Obecność białka TEX14 potwierdzono także w ludzkich jądrach [128] i od razu pojawił się pomysł by wykorzystać to odkrycie do opracowania metody antykoncepcji. Koleje atrakcyjne pole to badania zaburzeń cytokinezy. Wiadomo, że w wielu typach nowotworów (rak piersi, trzustki czy prostaty) dochodzi do defektów cytokinezy [129] a badania sugerują, że powstawanie pewnego typu nowotworu jąder (neoplazja komórek zarodkowych in situ) może mieć związek $\mathrm{z}$ niewłaściwym formowaniem SMM [130].

Dziś uważa się, że ZKP powstały bardzo wcześnie w ewolucji zwierząt wielokomórkowych [7]. Zespoły w linii męskiej i żeńskiej funkcjonują u parzydełkowców (stułbia, krążkopławy i koralowce), zwierząt które pojawiły się 720 milionów lat temu, a powstanie mechanizmu niepełnej cytokinezy najprawdopodobniej miało miejsce jeszcze przed powstaniem zwierząt wielokomórkowych, czego dowodem jest tworzenie mostków u wiciowców z grupy Choanoflagellata [131,132]. Mechanizm niepełnej cytokinezy pojawił się więc przed powstaniem zwierząt wielokomórkowych i został później zaadoptowany do takich funkcji jak wzajemne doposażanie haploidalnych spermatyd w brakujące produkty genowe, czy jednokierunkowy transfer cytoplazmy w przypadku oogenezy. I tu pojawia się kolejne wyzwanie dla badaczy - wyjaśnienie faktu, dlaczego u wielu zwierząt nie obserwuje się $\mathrm{w}$ ogóle formowania ZKP (szczególnie w linii żeńskiej). Skoro ZKP spełniają tak wiele ważnych funkcji to jakie mechanizmy kompensują ich brak?

\section{PODZIĘKOWANIA}

Autorzy dziękują dr Łukaszowi Chajcowi za wykonanie schematów. Dziękujemy dr hab. Izabeli Poprawie, dr Szymonowi Gorgoniowi i dr Karolowi Małocie za przeczytanie manuskryptu i uwagi.

\section{BIBLIOGRAFIA}

1. Jura C, Klag J (2005) Podstawy embriologii zwierząt i człowieka. Wydawnictwo Naukowe PWN, Warszawa 
2. Eckelbarger KJ, Hodgson AN (2021) Invertebrate oogenesis - a review and synthesis: comparative ovarian morphology, accessory cell function and the origins of yolk precursors. Invertebr Reprod Dev 65: 71140

3. Greenbaum MP, Iwamori T, Buchold GM, Matzuk MM (2011) Germ cell intercellular bridges. Cold Spring Harb Perspect Biol 3: a005850

4. Haglund K, Nezis IP, Stenmark H (2011) Structure and functions of stable intercellular bridges formed by incomplete cytokinesis during development. Commun Integr Biol 4: 1-9

5. Świątek P, Małota K, Hyra M, Gorgoń S, Poprawa I (2014) Stabilne mostki międzykomórkowe - kanały komunikacji międzykomórkowej. Postępy Biol Komórki 3: 507-532

6. Bilinski SM, Kubiak JZ, Kloc M (2017) Asymmetric divisions in oogenesis. Results and problems in cell differentiation. Springer, Cham, str. 211-228

7. Lu K, Jensen L, Lei L, Yamashita YM (2017) Stay Connected: A Germ Cell Strategy. Trends Genet 33: 971-978

8. Yamashita YM (2018) Subcellular specialization and organelle behavior in germ cells. Genetics 208: 19-51

9. Ventelä S (2006) Cytoplasmic bridges as cell-cell channels of germ cells, W: Baluska F, Volkmann D, Barlow P (red) Cell-Cell Channels. Springer, New York, str. 208-216

10. Pepling M, Lei L (2018) Germ cell nests and germline cysts. Encycl Reprod: $159-166$

11. Pepling ME, De Cuevas M, Sprading AC (1999) Germline cysts: A conserved phase of germ cell development? Trends Cell Biol 9: 257-262

12. Świątek P, Urbisz AZ (2019) Architecture and life history of female germ-line cysts in clitellate annelids, W: Tworzydlo W, Bilinski SM (red) Evo-Devo: Non-model Species in Cell and Developmental Biology, Results and Problems in Cell Differentiation. Springer, Switzerland, str. 515-551

13. Ikami K, Nuzhat N, Lei L (2017) Organelle transport during mouse oocyte differentiation in germline cysts. Curr Opin Cell Biol 44: 14-19

14. Guizetti J, Gerlich D (2010) Cytokinetic abscission in animal cells. Semin Cell Dev Biol 21: 909-916

15. Cartwright J, Arnold J (1980) Intercellular bridges in the embryo of the Atlantic squid, Loligo pealei. I. Cytoplasmic continuity and tissue differentiation. J Embryol Exp Morphol 57: 3-24

16. Airoldi SJ, McLean PF, Shimada Y, Cooley L (2011) Intercellular protein movement in syncytial Drosophila follicle cells. J Cell Sci 124: 40774086

17. Ganem NJ, Storchova Z, Pellman D (2007) Tetraploidy, aneuploidy and cancer. Curr Opin Genet Dev 17: 157-162

18. Weaver B, Cleveland D (2006) Does aneuploidy cause cancer? Curr Opin Cell Biol 18: 658-667

19. Margall-Ducos G, Celton-Morizur S, Couton D, Brégerie O, Desdouets C (2007) Liver tetraploidization is controlled by a new process of incomplete cytokinesis. J Cell Sci 120: 3633-3639

20. Roosen-Runge EC (1977) The process of spermatogenesis in animals. Cambridge University Press, Cambridge

21. Godula J (1998) Spermatogeneza bezkręgowców, W: Łukaszyk A Bilińska B, Kawiak J, Bielańska-Osuchowska Z (red) Ultrastruktura i funkcja komórki. Wydawnictwo Naukowe PWN, Warszawa, str. 1151

22. Yoshida S (2016) From cyst to tubule: Innovations in vertebrate spermatogenesis. Wiley Interdiscip Rev Dev Biol 5: 119-131

23. Fuller M (1993) Spermatogenesis. The development of Drosophila melanogaster. Cold Spring Harbor Laboratory Press, New York, str. 71-147

24. Guo GQ, Zheng GC (2004) Hypotheses for the functions of intercellular bridges in male germ cell development and its cellular mechanisms. J Theor Biol 229: 139-146

25. Büning J (1994) The Insect Ovary: Ultrastructure, previtellogenic growth and evolution. Chapman and Hall, London

26. Tworzydlo W, Kisiel E, Jankowska W, Bilinski SM (2014) Morphology and ultrastructure of the germarium in panoistic ovarioles of a basal 'apterygotous' insect, Thermobia domestica. Zoology 117: 200-206
27. Jedrzejowska I, Kubrakiewicz J (2007) The Balbiani body in the oocytes of a common cellar spider, Pholcus phalangioides (Araneae: Pholcidae). Arthropod Struct Dev 36: 317-326

28. de Jong-Brink M, Boer H, Joosse J. Mollusca (1983) W: Adiyodi K, Adiyodi R (red) Reproductive biology of invertebrates, Oogenesis, oviposition, and oosorption. Wiley, Chichester, str. 397-354

29. Świątek P, Płachno BJ, Marchant R, Gorgoń S, Krodkiewska M, Małota K, Urbisz AZ (2016) Germ-line cells do not form syncytial cysts in the ovaries of the basal clitellate annelid Capilloventer australis. Zool Anz 260: 63-71

30. Jedrzejowska I, Mazurkiewicz-Kania M, Garbiec A, Kubrakiewicz J (2013) Differentiation and function of the ovarian somatic cells in the pseudoscorpion, Chelifer cancroides (Linnaeus, 1761) (Chelicerata: Arachnida: Pseudoscorpionida). Arthropod Struct Dev 42: 27-36

31. Eckelbarger KJ (1983) Evolutionary radiation in polychaete ovaries and vitellogenic mechanisms: their possible role in life history patterns. Can J Zool 61: 487-504

32. Poprawa I, Janelt K (2019) Reproduction, gonad structure and oogenesis in tardigrades, W: Tworzydlo W, Bilinski SM (red) Evo-Devo: Non-model Species in Cell and Developmental Biology, Results and Problems in Cell Differentiation. Springer, Switzerland, str. 495-513

33. Wolke U, Jezuit E, Priess J (2007) Actin-dependent cytoplasmic streaming in C. elegans oogenesis. Development 134: 2227-2236

34. Amini R, Goupil E, Labella S, Zetka M, Maddox AS, Labbé J-C, Chartier NT (2014) C. elegans Anillin proteins regulate intercellular bridge stability and germline syncytial organization. J Cell Biol 206: 129-43

35. Żelazowska M, Fopp-Bayat D (2017) Ovarian nests in cultured females of the Siberian sturgeon Acipenser baerii (Chondrostei, Acipenseriformes). J Morphol 278: 1438-1449

36. Jaglarz MK, Bilinski SM (2020) Oogenesis in Crustaceans: ultrastructural aspects and selected regulating factors, W: Cothran RD, Thiel M (red) Reproductive Biology. Oxford University Press, Oxford, New York, str. 29-59

37. Kloc M, Biliński S, Dougherty MT, Brey EM, Etkin LD (2004) Formation, architecture and polarity of female germline cyst in Xenopus. Dev Biol 266: 43-61

38. Lei L, Spradling AC (2016) Mouse oocytes differentiate through organelle enrichment from sister cyst germ cells. Science 352: 95-99

39. De Cuevas M, Lilly MA, Spradling AC (1997) Germline cyst formation in Drosophila. Annu Rev Genet 31: 405-428

40. Huynh JR, St Johnston D (2004) The origin of asymmetry: Early polarisation of the Drosophila germline cyst and oocyte. Curr Biol 14: 438-449

41. Rehain-Bell K, Love A, Werner ME, MacLeod I, Yates JR, Maddox AS (2017) A sterile 20 family kinase and its co-factor CCM-3 regulate contractile ring proteins on germline intercellular bridges. Curr Biol 27: 860-867

42. Seidel H, Smith T, Evans J, Stamper J, Mast T, Kimble J (2018) C. elegans germ cells divide and differentiate in a folded tissue. Dev Biol 442: 173187

43. Janelt K, Jezierska M, Student S, Poprawa I (2020) Structure of the germarium and female germ-cell clusters in Thulinius ruffoi (Bertolani, 1982) (Tardigrada: Eutardigrada: Parachela). Zool J Linn Soc 188: 776787

44. Biliński S (1998) Ovaries, oogenesis and insect phylogeny. Introductory remarks. Folia Histochem Cytobiol 36: 143-145

45. Anderson E, Huebner E (1968) Development of the oocyte and its accessory cells of the polychaete, Diopatra cuprea (Bosc). J Morphol 126: 163-197

46. Huebner E, Anderson E (1976) Comparative Spiralian Oogenesis-Structural Aspects: An Overview. Am Zool 16: 315-343

47. Biliński S (1983) Differentiation of the oocyte and nurse cells in an apterygote insect (Campodea). Tissue Cell 15: 965-973

48. Criel G (1989) Morphological study of the ovary of Artemia, W: Warner A, MacRae T, Bagshaw J (red) Cell and molecular biology of Artemia development. Plenum, New York, str. 99-129 
49. Fawcett DW, Ito S, Slautterback D (1959) The occurrence of intercellular bridges in groups of cells exhibiting synchronous differentiation. J Biophys Biochem Cytol 5: 453-460

50. Leal MC, Cardoso ER, Nóbrega RH, Batlouni SR, Bogerd J, França LR, Schulz RW (2009) Histological and stereological evaluation of zebrafish (Danio rerio) spermatogenesis with an emphasis on spermatogonial generations. Biol Reprod 81: 177-187

51. Kubrakiewicz J (1997) Germ cells cluster organization in polytrophic ovaries of Neuroptera. Tissue Cell 29: 221-228

52. Pepling ME (2016) Nursing the oocyte. Science 352: 35-36

53. Deng W, Lin H (1997) Spectrosomes and fusomes anchor mitotic spindles during asymmetric germ cell divisions and facilitate the formation of a polarized microtubule array for oocyte specification in Drosophila. Dev Biol 189: 79-94

54. Matova N, Cooley L (2001) Comparative aspects of animal oogenesis. Dev Biol 231: 291-320

55. Ong S, Tan C (2010) Germline cyst formation and incomplete cytokinesis during Drosophila melanogaster oogenesis. Dev Biol 337: 84-98

56. McKearin D (1997) The Drosophila fusome, organelle biogenesis and germ cell differentiation: if you build it. BioEssays 19: 147-152

57. Huynh J-R (2006) Fusome as a cell-cell communication channel of Drosophila ovarian cyst, W: Baluska F, Volkmann D, Barlow P (red) Cell-Cell Channels. Springer, New York, str. 217-235

58. Jezierska M, Miernik A, Sojka J, Student S, Śliwińska MA, Gross V, Poprawa I (2021) Oogenesis in the tardigrade Hypsibius exemplaris Gąsiorek, Stec, Morek \& Michalczyk, 2018 (Eutardigrada, Hypsibiidae). Micron 150: 103126

59. Szklarzewicz T (1998) The ovaries of scale insects (Hemiptera, Coccinea). Morphology and phylogenetic conclusions. Folia Histochem Cytobiol 36: 157-165

60. Michalik A, Szklarzewicz T, Wegierek P, Wieczorek K (2013) The ovaries of aphids (Hemiptera, Sternorrhyncha, Aphidoidea): morphology and phylogenetic implications. Invertebr Biol 132: 226-240

61. Eikenes ÅH, Brech A, Stenmark H, Haglund K (2013) Spatiotemporal control of Cindr at ring canals during incomplete cytokinesis in the Drosophila male germline. Dev Biol 377: 9-20

62. Liana M, Witaliński W (2012) Female and male reproductive systems in the oribatid mite Hermannia gibba (Koch, 1839) (Oribatida: Desmonomata). Int J Acarol 38: 648-663

63. Gibert MA, Starck J, Beguet B (1984) Role of the gonad cytoplasmic core during oogenesis of the nematode Caenorhabditis elegans. Biol Cell 50: 77-85

64. Hirsh D, Oppenheim D, Klass M (1976) Development of the reproductive system of Caenorhabditis elegans. Dev Biol 49: 200-219

65. Leutert R (1974) Zur geschlechtsbestimmung und gametogenese von Bonellia viridis Rolando. Embryol Exp Morph 32: 169-193

66. Pilger JF (1980) The annual cycle of oogenesis, spawning, and larval settlement of the echiuran Listriolobus pelodes off Southern California. Pacific Sci 34: 129-142

67. Urbisz AZ, Chajec Ł, Świątek P (2015) The ovary of Tubifex tubifex (Clitellata, Naididae, Tubificinae) is composed of one, huge germ-line cyst that is enriched with cytoskeletal components. PLoS One 10: e0126173

68. Fischer A, Weigelt KR (1975) Strukturelle bezienhungen zwischen jungen oocyten und somatischen zellen bei den anneliden Platyneris und Piscicola. Verhandlungen Der Dtsch Zool Gesellschaft 67: 319-323

69. Spałek-Wołczyńska A, Klag J, Bielecki A, Świątek P (2008) Oogenesis in four species of Piscicola (Hirudinea, Rhynchobdellida). J Morphol 269: $18-28$

70. Urbisz AZ, Chajec Ł, Brąszewska-Zalewska A, Kubrakiewicz J, Świątek P (2017) Ovaries of the white worm (Enchytraeus albidus, Annelida, Clitellata) are composed of 16-celled meroistic germ-line cysts. Dev Biol 426: 28-42

71.Świątek P, Kubrakiewicz J, Klag J (2009) Formation of germ-line cysts with a central cytoplasmic core is accompanied by specific orientation of mitotic spindles and partitioning of existing intercellular bridges. Cell Tissue Res 337: 137-148
72. Małota K, Świątek P (2016) Analysis of the cytoskeleton organization and its possible functions in male earthworm germ-line cysts equipped with a cytophore. Cell Tissue Res 366: 175-189

73. Ben Ahmed R, Malota K, Jarosz N, Świątek P (2019) Microscopic analysis of spermatogenesis and mature spermatozoa in the amphibian leech Batracobdella algira (Annelida, Clitellata, Hirudinida). Protoplasma 256: 1609-1627

74. Olive PJW (1983) Annelida-Polychaeta, W: Adiyodi KG, Adiyodi RG (red) Reproductive Biology of Invertebrates. Oogenesis, Oviposition, and Oosorption, $\mathrm{t}$ I. John Wiley \& Sons, Chichester, str. 357-422

75. Jamieson BGM (1981) The ultrastructure of the Oligochaeta. Academic Press, London, New York, Toronto, Sydney, San Francisco

76. Krüger E, Hinssen H, D'Haese J (2008) Involvement of a gelsolin-related protein in spermatogenesis of the earthworm Lumbricus terrestris. Cell Tissue Res 332: 141-150

77. Fernandéz J, Tellez V, Olea N (1992) Hirudinea. Annelida, W: Harrison F, Gardiner S (red) Microscopic Anatomy of Invertebrates, 7 ed. Wiley-Liss, New York, str. 323-394

78. Ben Ahmed R, Tekaya S, Urbisz AZ, Światek P (2015) Ultrastructural study of spermatogenesis and sperm in the African medicinal leech Hirudo troctina Johnson, 1816 (Annelida, Hirudinida). Tissue Cell 47: 242-253

79. Ganot P, Bouquet JM, Kallesøe T, Thompson EM (2007) The Oikopleu$r a$ coenocyst, a unique chordate germ cell permitting rapid, extensive modulation of oocyte production. Dev Biol 32: 591-600

80. Suzuki AC (2006) Ovarian structure in Milnesium tardigradum (Tardigrada, Milnesiidae) during early vitellogenesis. Hydrobiologia 558: 6166

81. Dewel RA, Nelson DR, Dewel WC (1993) Tardigrada, W: Harrison FW, Rice ME (red) Microscopic Anatomy of Invertebrates. Wiley-Liss, New Yolk, str. 143-183

82. Lekimme M, Le Leclercq-Smekens M, Devignon C, Leclipteux T, Poumay Y, Losson B (2005) Ultrastructural morphology of the male and female genital tracts of Psoroptes spp. (Acari: Astigmata: Psoroptidae). Exp Appl Acarol 36: 305-324

83. Schwaha T, Gith R, Walzl MG (2008) The nutritive region in the ovaries of astigmatic mites (Acari: Acaridida). Soil Org 80: 249-259

84. Witaliński W (2014) Gonads and gametogenesis in astigmatic mites (Acariformes: Astigmata). Arthropod Struct Dev 43: 323-340

85. Witaliński W, Rozej-Pabijan E, Podkowa D (2014) Gonads in Histiostoma mites (Acariformes: Astigmata): Structure and development. Arthropod Struct Dev 43: 385-401

86. Ganot P, Moosmann-Schulmeister A, Thompson EM (2008) Oocyte selection is concurrent with meiosis resumption in the coenocystic oogenesis of Oikopleura. Dev Biol 324: 266-276

87. Ganot P, Kallesøe T, Thompson EM (2007) The cytoskeleton organizes germ nuclei with divergent fates and asynchronous cycles in a common cytoplasm during oogenesis in the chordate Oikopleura. Dev Biol 302: 577-590

88. Gottanka J, Büning J (1990) Oocytes develop from interconnected cystocytes in the panoistic ovary of Nemoura sp. (Pictet) (Plecoptera: Nemouridae). Int J Insect Morphol Embryol 19: 219-225

89. Jenkins VK, Timmons AK, McCall K (2013) Diversity of cell death pathways: insight from the fly ovary. Trends Cell Biol 23: 567-574

90. McCall K (2004) Eggs over easy: cell death in the Drosophila ovary. Dev Biol 274: 3-14

91. Brubacher JL, Huebner E (2009) Development of polarized female germline cysts in the polychaete, Ophryotrocha labronica. J Morphol 270: 413-429

92. Telfer WH (1975) Development and physiology of the oocyte-nurse cell syncytium. Adv In Insect Phys 11: 223-319

93. Poprawa I, Hyra M, Rost-Roszkowska MM (2015) Germ cell cluster organization and oogenesis in the tardigrade Dactylobiotus parthenogeneticus Bertolani, 1982 (Eutardigrada, Murrayidae). Protoplasma 252 1019-1029 
94. McKearin D, Dansereau DA, Lasko P (2005) Oogenesis, W: Gilbert L, Iatrou K, Gill SS (red) Comprehensive molecular insect science, t I. Reproduction and development. Elsevier, Amsterdam, str. 39-85

95. Serbus LR, Cha B-J, Theurkauf WE, Saxton WM (2005) Dynein and the actin cytoskeleton control kinesin-driven cytoplasmic streaming in Drosophila oocytes. Development 132: 3743-3752

96. Ganguly S, Williams LS, Palacios IM, Goldstein RE, Swinney HL (2012) Cytoplasmic streaming in Drosophila oocytes varies with kinesin activity and correlates with the microtubule cytoskeleton architecture. Proc Natl Acad Sci 109: 15109-15114

97. Doherty C, Diegmiller R, Kapasiawala M, Gavis E, Shvartsman S (2021) Coupled oscillators coordinate collective germline growth. Dev Cell 56: 860-870.e8

98. Baum J, St George J, McCall K (2005) Programmed cell death in the germline. Semin Cell Dev Biol 16: 245-259

99. Cavaliere V, Taddei C, Gargiulo G (1998) Apoptosis of nurse cells at the late stages of oogenesis of Drosophila melanogaster. Dev Genes Evol 208: 106-112

100. Mpakou VE, Velentzas AD, Velentzas PD, Margaritis LH, Stravopodis DJ, Papassideri IS (2011) Programmed cell death of the ovarian nurse cells during oogenesis of the ladybird beetle Adalia bipunctata (Coleoptera: Coccinellidae). Dev Growth Differ 53: 804-815

101. Peterson JS, McCall K (2013) Combined inhibition of autophagy and caspases fails to prevent developmental nurse cell death in the Drosophila melanogaster ovary. PLoS One 8: e76046

102. Gumienny TL, Lambie E, Hartwieg E, Horvitz HR, Hengartner MO (1999) Genetic control of programmed cell death in the Caenorhabditis elegans hermaphrodite germline. Development 126: 1011-1022

103. Nezis IP, Stravopodis DJ, Papassideri I, Robert-Nicoud M, Margaritis LH (2000) Stage-specific apoptotic patterns during Drosophila oogenesis. Eur J Cell Biol 79: 610-620

104. Paschma M (1962) The structure of the ovary and oogenesis in Enchytraeus albidus Henle. Zool Pol 12: 145-188

105. Alexandrova O, Schade M, Böttger A, David CN (2005) Oogenesis in Hydra: Nurse cells transfer cytoplasm directly to the growing oocyte. Dev Biol 281: 91-101

106. Miller MA, Technau U, Smith KM, Steele RE (2000) Oocyte development in Hydra involves selection from competent precursor cells. Dev Biol 224: 326-338

107. Böttger A, Alexandrova O (2007) Programmed cell death in Hydra. Semin Cancer Biol 17: 134-146

108. Pepling ME, Spradling AC (2001) Mouse ovarian germ cell cysts undergo programmed breakdown to form primordial follicles. Dev Biol 234: 339-351

109. Ventelä S, Toppari J, Parvinen M (2003) Intercellular organelle traffic through cytoplasmic bridges in early spermatids of the rat: mechanisms of haploid gene product sharing. Mol Biol Cell 14: 2768-80

110. Bartmańska J (1998) Przebieg i regulacja mitotycznej fazy procesu spermatogenezy ssaków, W: Łukaszyk A, Bilińska B, Kawiak J, Bielańska-Osuchowska Z (red) Ultrastruktura i funkcja komórki. Wydawnictwo Naukowe PWN, Warszawa, str. 166-197

111. Małota K, Student S, Świątek P (2019) Low mitochondrial activity within developing earthworm male germ-line cysts revealed by JC-1. Mitochondrion 44: 111-121

112. Rezende-Melo C, Caldeira-Brant A, Drumond-Bock A, Buchold G, Shetty G, Almeida F, Matzuk M, Hara K, Yoshida S, Meistrich M, Chiarini-Garcia H (2020) Spermatogonial asynchrony in Tex14 mutant mice lacking intercellular bridges. Reproduction 160: 205-215

113. Soygur B, Jaszczak R, Fries A, Nguyen D, Malki S, Hu G, Demir N, Arora R, Laird D (2021) Intercellular bridges coordinate the transi- tion from pluripotency to meiosis in mouse fetal oocytes. Sci Adv 7: eabc6747

114. Lilly M, de Cuevas M, Spradling A (2000) Cyclin A associates with the fusome during germline cyst formation in the Drosophila ovary. Dev Biol 218: 53-63

115. Braun RE, Behringer RR, Peschon JJ, Brinster RL, Palmiter RD (1989) Genetically haploid spermatids are phenotypically diploid. Nature 337: 373-376

116. Brill J, Hime G, Scharer-Schuksz M, Fuller MT (2000) A phospholipid kinase regulates actin organization and intercellular bridge formation during germline cytokinesis. Development 127: 3855-3864

117. Greenbaum MP, Yan W, Wu M-H, Lin Y-N, Agno JE, Sharma M, Braun RE, Rajkovic A, Matzuk MM (2006) TEX14 is essential for intercellular bridges and fertility in male mice. Proc Natl Acad Sci 103: 4982-4987

118. Rouse G (2006) Annelid sperm and spermiogenesis, W: Rouse G, Pleijel F (red) Reproductive biology and phylogeny of Annelida. Science Publishers, Enfield, str. 45-76

119. Lu KL, Yamashita YM (2017) Germ cell connectivity enhances cell death in response to DNA damage in the Drosophila testis. Elife 6: e27960

120. Gunes S, Al-Sadaan M, Agarwal A (2015) Spermatogenesis, DNA damage and DNA repair mechanisms in male infertility. Reprod Biomed Online 31: 309-319

121. Iwamori T, Iwamori N, Matsumoto M, Imai H, Ono E (2020) Novel localizations and interactions of intercellular bridge proteins revealed by proteomic profiling. Biol Reprod 102: 1134-1144

122. Greenbaum MP, Iwamori N, Agno JE, Matzuk MM (2009) Mouse TEX14 is required for embryonic germ cell intercellular bridges but not female fertility. Biol Reprod 80: 449-457

123. Ikami K, Nuzhat N, Abbott H, Pandoy R, Haky L, Spradling A, Tanner H, Lei L (2021) Altered germline cyst formation and oogenesis in Tex14 mutant mice. Biol Open 10: bio058807

124. Pepling ME, Wilhelm JE, O 'hara AL, Gephardt GW, Spradling AC (2007) Mouse oocytes within germ cell cysts and primordial follicles contain a Balbiani body. PNAS 104: 187-192

125. Kloc M, Jaglarz M, Dougherty M, Stewart MD, Nel-Themaat L, Bilinski S (2008) Mouse early oocytes are transiently polar: Three-dimensional and ultrastructural analysis. Exp Cell Res 314: 3245-3254

126. Ali-Murthy Z, Fetter RD, Wang W, Yang B, Royer LA, Kornberg TB (2021) Elimination of nurse cell nuclei that shuttle into oocytes during oogenesis. J Cell Biol 220: e202012101

127. Pepling ME (2006) From primordial germ cell to primordial follicle: mammalian female germ cell development. Genesis 44: 622-632

128. Greenbaum MP, Ma L, Matzuk MM (2007) Conversion of midbodies into germ cell intercellular bridges. Dev Biol 305: 389-396

129. Sagona A, Stenmark H (2010) Cytokinesis and cancer. FEBS Lett 584: 2652-2661

130. Gondos B, Berthelsen J, Skakkebaek N (1983) Intratubular germ cell neoplasia (carcinoma in situ): a preinvasive lesion of the testis. Ann Clin Lab Sci 13: 185-192

131. Dayel M, Alegado R, Fairclough S, Levin T, Nichols S, McDonald K, King N (2011) Cell differentiation and morphogenesis in the colony-forming choanoflagellate Salpingoeca rosetta. Dev Biol 357: 73-82

132. Fairclough SR, Dayel MJ, King N (2010) Multicellular development in a Choanoflagellate. Curr Biol 20: R875-R876 


\section{Germ-line cysts in animal gametogenesis - genesis, organization and functioning}

\section{Piotr Świątek ${ }^{\otimes}$, Anna Z. Urbisz}

Faculty of Natural Sciences, Institute of Biology, Biotechnology and Environmental Protection, University of Silesia in Katowice, Katowice, Poland

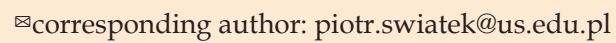

Key words: spermatogenesis, oogenesis, cell-to-cell communication, intercellular bridges

\section{ABSTRACT}

During early gametogenesis the incomplete mitotic divisions occur. The cytokinesis is blocked and the sister cells do not fully separate. Instead, they stay connected via modified contractile rings known as stable intercellular bridges or ring canals. Intercellular bridges are broad cytoplasmic strands (from $0,2 \mu \mathrm{m}$ to $20 \mu \mathrm{m}$ in diameter), which allow to exchange the gene products and organelles between interconnected cells. Such syncytial structures are termed germ-line cysts. As a rule, cysts are formed during spermatogenesis and they interconnect germ cells till sperm formation. In the female germ-line (oogenesis) cysts may not form at all, may be formed for a short period of time (till early meiosis) or may function till late oogenesis. Despite of universal mechanism of cysts formation (incomplete cytokinesis and bridge formation) there are substantial differences in cysts organization and functioning between taxa. The present paper gives the basic knowledge about formation and functioning of male and female germ-line cysts.

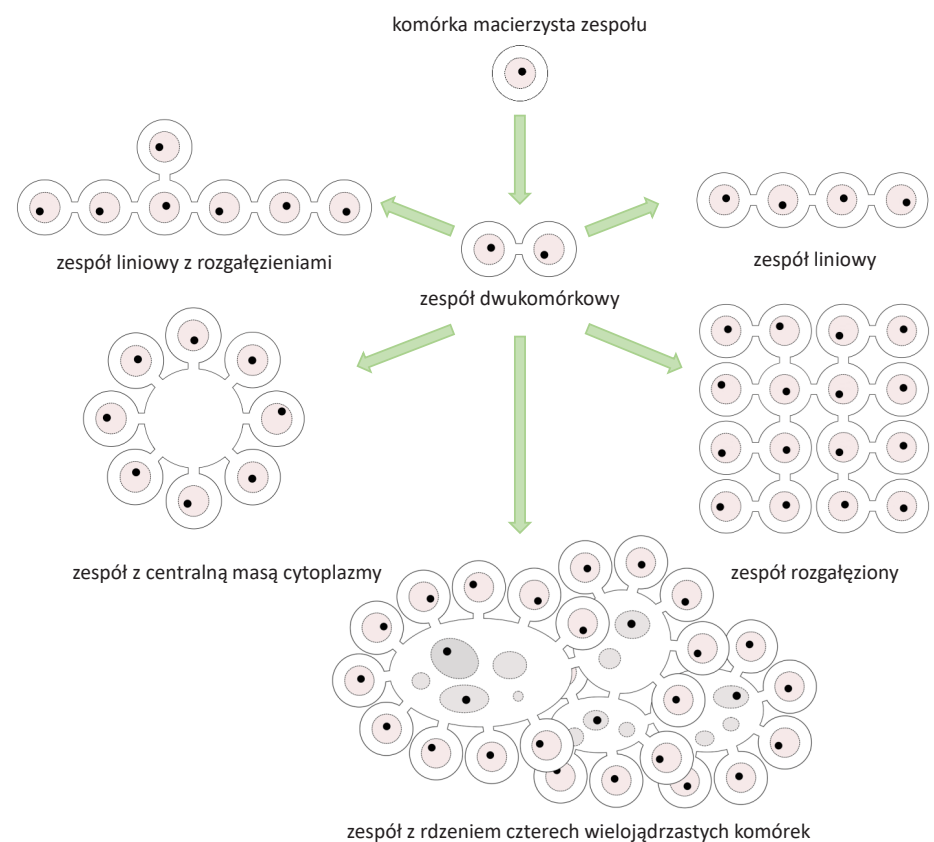

